\title{
Parallel Trade of Pharmaceuticals: The Danish Market for Statins *
}

\author{
Susan J. Méndez ${ }^{\dagger}$
}

\begin{abstract}
This paper investigates and quantifies the impact of parallel trade in markets for pharmaceuticals. The paper develops a structural model of demand and supply using data on price, sales and the characteristics of statins in Denmark and simulates outcomes under a complete ban of parallel imports, keeping other regulatory schemes unchanged. There are two sets of key results. The first set focuses on price effects. On average, prices increase more in markets where the molecule has lost patent protection; wholesale prices for both generic and original products increase after competition from parallel importers is removed, but the final price paid by consumers (after deducting reimbursement) increases more for original products than for generics because most changes in wholesale prices are absorbed by the prevailing reimbursement rules. The second set of results reports the effects on market participants. My model takes into consideration consumers' preferences, allowing them to substitute between products. Prohibiting parallel imports induces consumers to substitute towards original products for which they have stronger preferences. In sum, banning parallel imports leads to (i) an increase in variable profits for original producers and a decrease for generic firms, (ii) an increase in governmental health care expenditures, and (iii) a decrease in the welfare of Danish patients and firms.
\end{abstract}

Keywords: pharmaceutical markets, parallel trade, regulation, welfare analysis.

JEL Classification: I18, H51.

*I would like to thank Kurt Brekke, Ronny Gjendemsjø, Daniel Halbheer, Ulrich Kaiser, Anne Leahy, Franco Mariuzzo, Katja Seim, Kevin Staub, Hannes Ullrich, Jongsay Yong, and seminar participants at La Trobe University, Monash University, the University of Melbourne, the University of Zurich, the joint 2015 Annual Health Econometrics Workshop \& 7th. Australasian Workshop on Econometrics and Health Economics, the 28th. Annual Congress of the European Economic Association (EEA) 2013, the 40th. Annual Conference of the European Association for Research in Industrial Economics (EARIE) 2013, and the 7th. Competition Law and Economics European Network workshop (CLEEN) 2013 for helpful comments and suggestions. I am indebted to Jørgen Clausen of the Danish Association of the Pharmaceutical Industry (Lægemiddel Industri Foreningen; LIF) and Jens Nielsen of the Danish Medicines Agency (DKMA) for data provision and data advice. Financial support from the Swiss National Science Foundation through grant PBZHP1-138689 is gratefully acknowledged.

${ }^{\dagger}$ University of Melbourne, Melbourne Institute of Applied Economic and Social Research, 111 Barry Street, The University of Melbourne, VIC 3010, Australia, susan.mendez@unimelb.edu.au 


\section{Introduction}

Parallel trade refers to the practice where products are legally marketed in one country but distributed in another country without authorization of the property rights holder. In the European market for pharmaceuticals, governmental health care agencies attempt to provide innovative, safe, effective and affordable pharmaceuticals, while keeping costs under control. To reach this goal different regulatory policies across nations are in use. However, it has been argued that these differences in regulatory strategies generate significant price dispersion and hence induce arbitrage opportunities and a profitable market for parallel trade (Danzon 1998, Danzon and Chao 2000). Whether or not parallel imports in the pharmaceutical industry are beneficial for market participants has been an intensely debated issue. Opponents of parallel trade argue that parallel imports weaken intellectual property protection and therefore firms have less incentive to innovate, which generates dynamic inefficiency. Supporters, on the other hand, emphasize that parallel trade benefits consumers because it increases competition leading to lower prices, which in turn generates savings to consumers and insurers. In an attempt to reduce high prices for pharmaceutical products, the European Union has allowed parallel imports within its area. $^{1}$

The goal of this paper is to investigate the impact of parallel trade in markets for pharmaceuticals. More specifically, this paper attempts to identify and understand the effects of parallel imports on consumer consumption decisions, government expenditures for pharmaceuticals, and producer strategies.

I empirically quantify these effects on the market participants using data on price, sales and the characteristics of statins in Denmark. Statins are used in the treatment of hypercholesterolemia - the presence of high levels of cholesterol in the blood - a chronic condition that, if left unattended, can have severe consequences such as heart attack and stroke, both of which are leading causes of death in developed countries. The best known statins sell under the tradenames Lipitor (by Pfizer) and Zocor (by MSD Sharp \&5 Dohme) and are top selling medicines worldwide in terms of volume and revenue. The Danish pharmaceutical market provides a clean empirical setting to study these effects due to its unique market structure and the availability of very rich data. Denmark maintains a tax-financed universal public health insurance system that provides reimbursement for

\footnotetext{
${ }^{1}$ The United States currently referred bill S.319, Pharmaceutical Market Access and Drug Safety Act of 2011, to Senate committee on $2 / 10 / 2011$ to allow parallel imports.
} 
pharmaceutical products, but does not directly regulate the price setting decisions of the firms. Hence, a particularly attractive feature of my data is that it allows me to distinguish between the price set by the firm, the price set by the pharmacy and, most importantly, the price paid by consumers, which plays the most important role in determining demand. In addition to the detailed information on how prices are established at different stages of the vertical supply chain, the stringent regulation on pricing eliminates the need to model behavior at the distribution stage of the vertical chain, allowing for a focus on consumers and firms only. ${ }^{2}$

The paper consists of two parts. The first part develops and estimates a structural model of demand and supply under current regulation laws and market structure. The second part uses estimates of the model parameters and the provided framework to construct counterfactuals, allowing for a static welfare evaluation for Denmark under a complete ban of parallel imports.

Eliminating parallel trade yields the following results. First, a prohibition of parallel trade reduces unweighted average prices but results in higher prices for both original products and generic products. Second, eliminating parallel trade leads to substitution from parallel imported products towards original products. Third, consumer expenditures as well as government expenditures increase in the absence of parallel trade. Finally, banning parallel imports reduces consumer surplus and increases firm profits, on balance leading to an overall decrease in welfare for this market.

Finally, while beyond the scope of this paper the long-term effects of parallel trade, particularly in generating dynamic inefficiencies that can reduce welfare, remain a highly controversial and unresolved question, which is a characteristic of an industry that heavily relies on $R \& D$ and innovation as an important driver of consumer welfare. Furthermore, for a complete welfare analysis it would be necessary to consider the interconnectedness of markets. Welfare evaluation should assess the effects of parallel trade in importing countries as well as exporting countries. These questions constitute important issues for further research.

This paper is organized as follows. Section 2 provides a review of the relevant literature. Section 3 offers an overview of the Danish pharmaceutical market. Section 4 describes the data. Section 5 describes the empirical framework and describes the simulation strategy.

\footnotetext{
${ }^{2}$ In recent and novel work by Dubois and Sæthre (2017), the authors investigate how parallel trade influences the distribution of profits. They explicitly model and estimate a bargaining model between pharmacy retailers and pharmaceutical companies and thus account for the vertical structure of the market.
} 
Section 6 presents the results and implications. Section 7 concludes.

\section{Literature Review}

This section offers a short summary of the literature on parallel imports. First, I present the legal framework on parallel trade in the European Union. Next, I review the literature that has addressed parallel imports in the pharmaceutical industry from an economics perspective.

\section{A Legal Perspective}

Parallel trade deals with topics in three related fields: intellectual property law, international trade, and competition law. ${ }^{3}$

International research-intensive firms rely strongly on intellectual property rights to protect their investments. One important aspect is the legal principle of exhaustion of patent rights, which determines the markets where the property right owner can prevent unauthorized trade. Under the Trade-Related Aspects of Intellectual Property Rights Agreement (TRIPS), each signature country is free to determine a national or an international policy of exhaustion of patent rights (Article 6 of the TRIPS Agreement). The European Union has adopted a policy of community exhaustion, such that property right owners can prevent resale of products first sold outside the area, but cannot interfere in the trade of its products within members states of the European Union.

Furthermore, in an effort to achieve and protect the European common market, the European Commission and the European Court of Justice strictly enforce the principle of free movement of goods within the European Union (Article 28 of the consolidated version of the Treaty on the Functioning of the European Union (TFEU)).

Firms producing original products have used different strategies to limit parallel trade, such as challenging restrictive distribution agreements with wholesalers, setting supply restrictions in exporter countries, or challenging trademark protection. ${ }^{4}$ But parallel trade within the European Union has been enabled and protected through these laws, which prioritize the principle of a common market over the possible welfare losses generated

\footnotetext{
${ }^{3}$ See Kyle (2009) for an overview of the literature related to parallel trade in pharmaceuticals

${ }^{4}$ See for example: GlaxoSmithKline Services Unlimited v. Commission of the European Communities Case C-501/06, 2009 ECR I-9291; GlaxoGroup Ltd. v. Dowelhurst Ltd. \& Anor Case HC 03 00464, 2003 EWHC 2015; Hoffman-La Roche v. Centrafarm Case C-1 02/77, 1978 ECR 1139.
} 
through reduced incentives to innovate. More recent cases have shed light on the importance of considering dynamic inefficiencies (Petrucci 2010, Tsouloufas 2011) and the necessity of revising the goals of the EU competition laws (Kyle 2016).

\section{An Economic Perspective}

Most of the empirical studies on parallel imports in the pharmaceutical industry have almost exclusively focused on price effects. For instance, Ganslandt and Maskus (2004) use a regulatory change after Sweden joined the European Union in 1995. They estimate a 19 percent price reduction due to parallel imports for the top 50 molecules in Sweden. ${ }^{5}$ In contrast, Kanavos and Costa-Font (2005) study six molecules in 11 European countries during 1997 to 2002. They attribute price decreases in import countries not to parallel trade but, rather, to generic substitution, and they find evidence for the entry of parallel importers to be determined by price differences between countries. A contribution that takes a different approach is Kyle (2011). She investigates non-price responses to parallel trade because, in this heavily regulated industry, firms are usually limited in the price setting strategies they can adopt in order to compete with parallel trade. Her study reveals that to counteract the competitive pressure from parallel importers original firms are indeed using non-price strategies to hinder parallel trade, typically by restricting supply, using restrictive distribution agreements and differentiating products across countries by altering the brand name, dosage form and strength.

A related study is Enemark et al. (2006). The authors use data for four European countries, including Denmark, on the top 50 pharmaceutical products in 2004. They use a reduced-form approach and the prices of original products before any competing parallel importer enters the market to predict how prices would have developed in the absence of parallel imports. They find that parallel trade generated 168 million Danish krones in savings. My results contribute to the view that parallel trade does generate substantial savings for consumers and health care agencies. However, in contrast to Enemark et al. (2006), I explicitly model and structurally estimate the change in prices taking into consideration price elasticities, patient preferences and the strategic reaction of firms. The magnitude of the savings predicted in my model is much higher (on average 242.6 million Danish krones in the market for statins) than the results in Enemark et al. (2006), and my

\footnotetext{
${ }^{5} \mathrm{~A}$ molecule in this context is the active ingredient of a pharmaceutical product defined by its bottom-level Anatomical Therapeutic Chemical (ATC) classification code.
} 
model highlights the importance of considering the more complex interactions between pharmaceutical companies, insurance providers and patients.

Finally, in a contemporaneous paper Duso et al. (2014) examine the welfare effects of parallel trade using data on the German market for oral anti-diabetic drugs. Their results suggest a decrease in prices for on-patent products of 11 percent, no effects for generics, and a modest impact on consumer surplus. Although the geographic and therapeutic markets are different from the ones examined here, their results support my findings. However, my predicted price effects are smaller (around 3 percent) and my welfare effects are substantial (around 18 percent of the yearly market's revenue). This can be attributed to my having a richer data set that allows me to use more precise information, such as firm prices, to calculate firm profits; pharmacy prices to calculate governmental savings and consumer prices; which are not fixed to certain levels but vary for each product, to calculate patients' price sensitivity more accurately. In addition, Denmark does not impose minimum quotas directly on the sale of parallel imports at the pharmacy level, nor does it use rebate contracts in the procurement for pharmaceuticals, both of which facilitate a more clean setting in which to investigate my question.

The theoretical literature has gone beyond studying price effects and explores the impact of parallel trade on R\&D. Li and Maskus (2006), Szymanski and Valletti (2006), and Valletti (2006) conclude that parallel imports have a detrimental effect on incentives to innovate in the long run, but can be beneficial to consumers in the short run. However, Grossman and Lai (2008) show that allowing international parallel trade can benefit innovation, since governments could use different price control tools if international parallel trade were permitted. This issue, while beyond the scope of my paper, is still a relevant question.

\section{The Danish Pharmaceutical Industry}

This section offers an overview of the pharmaceutical industry and discusses the main regulatory framework in effect during the time period covered by my data (May 2003 to March 2005). 


\subsection{Industry Description}

The pharmaceutical industry in Denmark has a typical vertical structure. ${ }^{6}$ First, at the upstream level there are three types of firms: original firms, generic firms, and parallel importers. Original firms engage in $\mathrm{R} \& \mathrm{D}$ and manufacture new medicines using intellectual property rights to protect their innovations. Generic firms produce bioequivalent copies of original products and are only allowed to enter the market after the relevant patents have expired. In contrast, parallel importers do not engage in manufacturing, but rather they supply products that are imported from markets outside of Denmark. Typically, parallel importers repackage, relabel, and redistribute (original and generic) products. Since 1990 parallel imports have been legal in Denmark - even for products under patent protection.

Second, at the wholesale level, pharmacies purchase pharmaceuticals from upstream firms that are supplied to consumers (patients). Pharmacies operate in a highly regulated market environment, as I detail below. The most important features of the regulation are generic substitution and retail price regulation.

Finally, at the downstream level, consumers purchase prescription-only pharmaceuticals from the pharmacies. At the consumer level, the regulator implemented a system of reference pricing that sets reimbursement rules. Importantly, the reimbursement price determines copayment prices, which in turn determine consumers' purchase decisions. Figure 1 illustrates the vertical structure.

Other relevant market features are that Denmark maintains a universal health care system that is financed through general tax revenues; advertising prescription drugs directly to patients is prohibited; and detailing (marketing to physicians) is highly regulated and only allowed in the case of original firms introducing new molecules.

\subsection{Regulatory Framework}

Governmental safety concerns and budget constraints generate a high degree of regulation on pharmaceutical markets. In Europe, price regulation and reimbursement rules relating to pharmaceuticals is a national decision. Denmark's regulatory body has adopted a policy of free pricing at the upstream level. However, the upstream firms must report their prices to the Danish Medicines Agency (DKMA). Every second week, the DKMA updates prices and product availability in a publicly available list. This list is used by

\footnotetext{
${ }^{6}$ Evidence for vertical differentiation in the market for pharmaceuticals has been provided by Brekke et al. (2011), Ching (2010a,b), Grabowski and Vernon (1992), Scott Morton (2000) among others.
} 


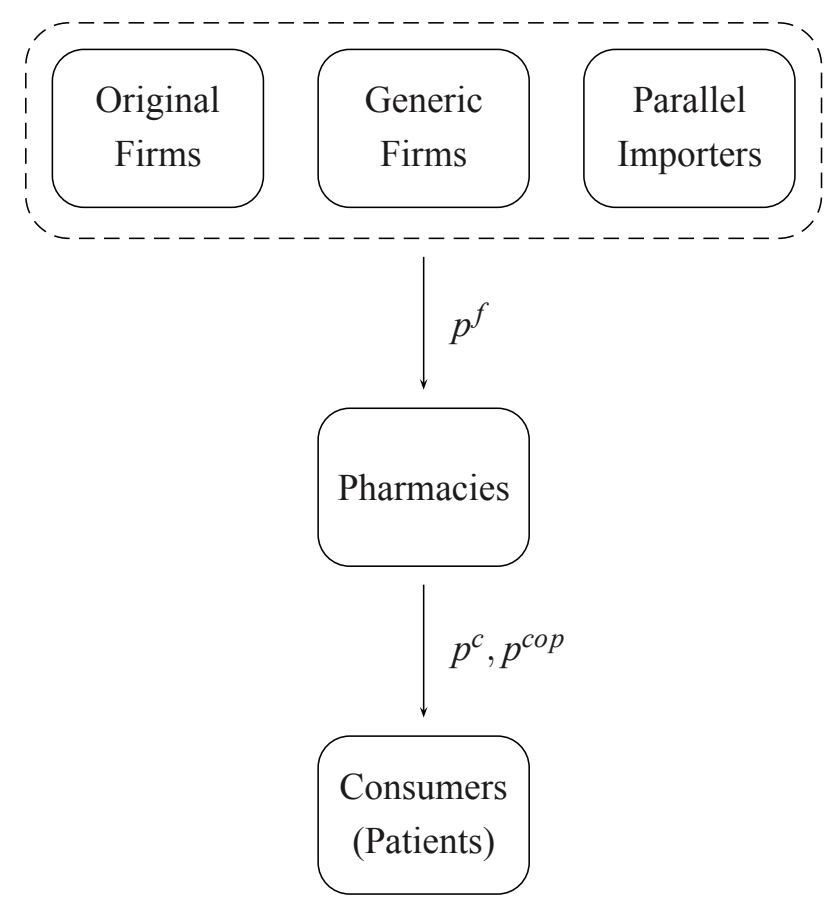

Figure 1: Overview of vertical industry structure

doctors when issuing prescriptions, by hospitals for their electronic patient records, by pharmacies to ensure availability of products, and by consumers to obtain information about (copayment) prices of available substitutes. Next, I discuss pharmacy regulation and follow it with a description of the reimbursement rules that determine copayment prices.

\subsubsection{Pharmacy Regulation}

Pharmacies face two types of regulation: generic substitution and retail price regulation. Danish pharmacists are required by law to dispense the cheapest product among available substitutes, unless the consumer or the doctor explicitly requests another product. Generic substitution for off-patent products has been encouraged since 1991.

Pharmacy retail prices $p^{c}$ for prescription-only pharmaceuticals are identical nationwide and can be decomposed as follows:

$$
p^{c}=\mu p^{f}+k,
$$

where $p^{f}$ is the pharmacy purchase price (at the wholesale level), $\mu$ is the regulated 
markup above the pharmacy purchase price, and $k$ is the prescription fee (including value added tax.${ }^{7}$ Notice that, in effect, retail price regulation determines pharmacies' unit margins.

\subsubsection{Reimbursement Rules}

The final price paid by consumers is the copayment price, that is, the pharmacy retail price adjusted for reimbursement. Specifically, the copayment price $p^{c o p}$ is given by:

$$
p^{c o p}=p^{c}-0.8 * p^{r}
$$

where $p^{c}$ is the pharmacy retail price and $p^{r}$ is the reference price. The reference price for a given product is set equal to its own pharmacy retail price as long as it is below the average price in EU-15 (excluding Greece, Luxembourg, Spain, and Portugal). 8 The 80percent reimbursement of the reference price applies for consumers with yearly expenditures exceeding 2,950 Danish krones (DKK) (€395). ${ }^{9}$

Substitution groups are defined by DKMA guidelines. Products are assigned to the same substitution group if they have the same active ingredient, administration form, strength, and similar package size. Importantly, consumers can freely choose among products in the same substitution group.

This reimbursement rule, while allowing consumers some freedom of choice, does influence consumers' price sensitivity by covering only a fraction of their expenditures. Therefore, reference pricing is a widely used measure for cost containment (López-Casasnovas and Puig-Junoy 2000; Espín et al. 2011). ${ }^{10}$ Brekke et al. (2007, 2009, 2011), Kaiser et al. (2014), and Pavcnik (2002) empirically investigate the impact of reference pricing on consumer and government expenditures.

\footnotetext{
${ }^{7}$ The exact rules and yearly adjustments to compute pharmacy retail prices from pharmacy purchase prices are detailed in Appendix A.

${ }^{8}$ EU-15 refers to the following member countries of the European Union: Austria, Belgium, Denmark, Finland, France, Germany, Greece, Ireland, Italy, Luxembourg, the Netherlands, Portugal, Spain, Sweden and the United Kingdom.

${ }^{9}$ The medical condition explored below is a chronic condition for which this minimum expenditure is reached.

${ }^{10}$ The WHO Collaborating Centre for Pharmaceutical Pricing and Reimbursement Policies (online access at http://whocc.goeg.at) offers an overview of the countries that currently use reference pricing to control expenditures.
} 


\section{The Data}

I use data from the market of statins during the time period May 2003 to March 2005. Price data and product characteristics were obtained from DKMA. Sales data was made available from the Danish Association of the Pharmaceutical Industry (LIF). I observe fortnightly prices and sales for 213 products sold in Denmark which belong to the molecules in the therapeutic group of HMG CoA reductase inhibitors (commonly known as statins).

A product is defined by four attributes: active substance, strength, package size, and firm. The active substance is captured by the molecule classified by the 5-level ATC code. Strength measures the amount of the active substance in milligrams per pill. Package size is simply the number of pills per package.

There are six molecules, out of which three are off-patent or have lost patent protection during the observed time period (Simvastatin, Lovastatin, and Pravastatin). The other molecules are on-patent (Fluvastatin, Atorvastatin, and Rosuvastatin). Table 1 provides an overview and indicates the ATC codes. In addition, the table provides information about brand names, patent owners and the average number of firms and products in each molecule. The best known statins sell under the tradenames Lipitor (Pfizer) and Zocor (MSD Sharp $\&$ Dohme) and are top selling medicines in terms of quantity and revenue. In 2004 the Danish market for statins generated around DKK 320 million (€ 43 million).

Generic firms also sell versions of the first three molecules (C10AA01-C10AA03). In contrast, the molecules Fluvastatin (C10AA04), Atorvastatin (C10AA05) and Rosuvastatin (C10AA07) are protected by an active patent and sold by original firms and parallel importers only.

To make different products comparable I normalize prices and quantities using defined daily doses (DDD). This measure is proposed by the World Health Organization and widely used in the pharmaceutical industry.

Table 2 shows average pharmacy purchase prices $p^{f}$, reference prices $p^{r}$ and copayment prices $p^{c o p}$. All prices are deflated using the consumer price index with 2005 as basis year. The summary is organized as follows: Part A shows averages for all products, Part B presents the results by molecule, Part C by firm type, and Part D by the patent status. Pharmacies buy one DDD for around DKK 6 (around $€ 0.80$ ) and consumers' copayment is on average DKK $3.2(€ 0.40)$. As noted in Kanavos and Costa-Font (2005), the pharmacy purchase price for parallel imports lies just below the price for original 
products and significantly above generic prices. This could be attributed to the fact that most of the parallel imported products are potentially produced by original firms. This is clear for the three on-patent molecules, and while for the off-patent molecules I do not directly observe the country that exported the parallel imported product, I use as a proxy information about the name under which the product is marketed in Denmark. For safety reasons this should be the same trade name under which the product is marketed in the exporting country and generic firms cannot use trademark protected names. Finally, copayments seem to be substantially higher for original products than for parallel imports or generics. Also, consumers pay more for off-patent products than for on-patent products due to the reimbursement rules and the lack of substitutes in the on-patent segment. More specifically, the reference price used to calculate reimbursement is set within each substitution group, which in turn are narrowly defined (products are assigned to the same substitution group if they have the same active ingredient, administration form, strength, and similar package size). As a consequence, products that are on-patent might be the only product in a substitution group and its own retail price will be used as the reference price. Thus the reimbursement that the patient receives is the highest. This is clearly seen in Table 2. If we compare C10AA01 (off-patent) and C10AA05 (on-patent) we see that the difference in pharmacy purchase prices is much larger than the difference in copayment prices. Price regulation and reimbursement rules will play an important role for the counterfactual estimation, in which I find that changes in wholesale prices generated by a prohibition of parallel trade are absorbed mostly by the government and less so by the consumer. ${ }^{11}$

Further, Figure 2 shows average pharmacy purchase prices per DDD over time for each type of firm in the six different molecules. Prices for original products are very stable even in the presence of generic products or parallel imports. On the contrary, parallel imports seem to compete with generics once they enter the market. This is mainly visible in the graphic from Lovastatin (C10AA02) and Pravastatin (C10AA03) where generic entry is clearly observed and is followed by a drop in average prices from parallel imports and generics.

Finally, Table 3 summarizes average sales, revenues and expenditures. Fortnightly sales are in volume terms and amount to about 2.4 million DDD on average for a period

\footnotetext{
${ }^{11}$ The relationship between price regulation and parallel trade has been recently explored by Brekke et al. (2015). The authors find evidence that, in the presence of parallel trade, price regulation might improve static efficiency without being harmful for dynamic efficiency.
} 

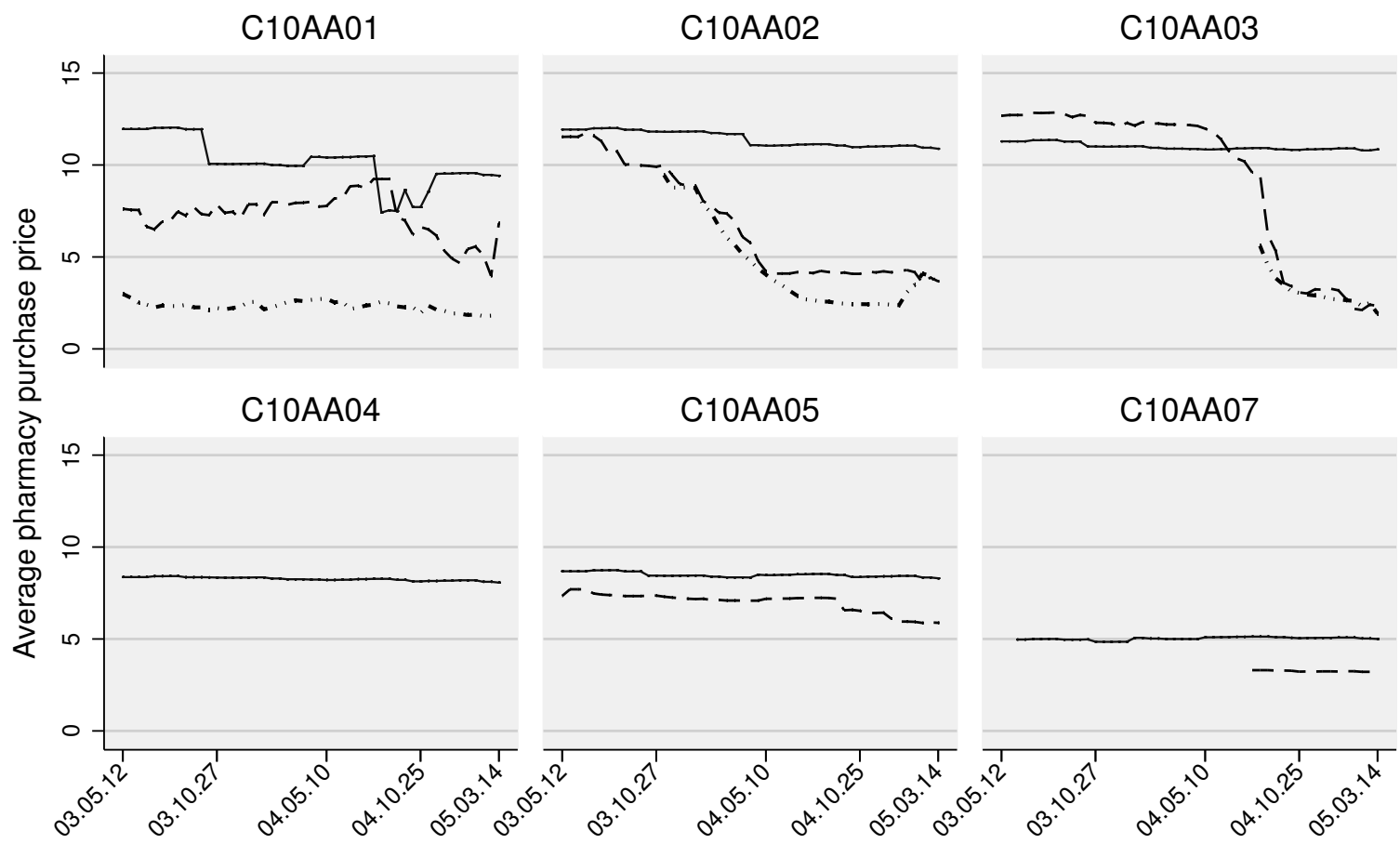

Period

Original products $\quad$-..... Generic products

Parallel imports

Figure 2: Average pharmacy purchase price over time

of 14 days. The most popular products are Simvastatin (C10AA01) and Atorvastatin (C10AA05), which sell on average at a forthnightly rate of around 1.7 million DDD and 0.5 million DDD respectively. Furthermore, most sales come from generic products. Revenues are calculated as pharmacy purchase price times sold DDDs. The fortnightly market for statins is worth on average DKK 9 million. Original firms account for the highest revenues, while revenues for generics and parallel imports are substantially lower. Government expenditure, in the form of reimbursement costs, amounts to DKK 10.3 million on average for a period of 14 days. Finally, consumers pay only a fraction of the cost (copayment price times consumed DDDs); their fortnightly expenditures are on average DKK 3.3 million. 


\section{Empirical Framework}

The empirical framework has two main components: demand estimation and supply estimation. The estimation draws on Berry (1994), Stern (1996), and Verboven (1996), and contributes to a growing literature on structural estimation in the pharmaceutical industry, as seen in recent work by Branstetter et al. (2016), Ching (2010a, 2010b), Dubois and Lasio (2014), Dunn (2012), Dutta (2011), and Kaiser et al. (2014). The first part of this paper specifies a discrete choice model to estimate consumer demand. These estimates are used in the second part to recover the marginal cost of production from firms' profit maximizing conditions. Ultimately, the goal of the analysis is to use the estimates to generate policy implications of a hypothetical ban of parallel imports.

\subsection{Demand Estimation}

I consider a market with a set of consumers that are indexed by $i$. Each consumer chooses the product $j(j=1, \ldots, J)$ that maximizes her utility $U_{i j}$. Consumer choice has a nested logit structure (Berry 1994). The nest structure follows from substitution groups defined by the DKMA and represents the prescription ordered by the practitioner. Each nest $(g=1, \ldots, G)$ includes all original, generic and parallel imported available products in the same substitution group. Importantly, consumers can freely choose among products in the same substitution group. ${ }^{12}$

The utility of a consumer as a function of observed and unobserved product characteristics is:

$$
U_{i j}=X_{j} \beta-\alpha p_{j}^{c o p}+\xi_{j}+\sum_{g}\left[d_{j g} \zeta_{i g}\right]+(1-\sigma) \varepsilon_{i j}
$$

The terms that are invariant across consumers are captured by mean utility $\delta_{j} \equiv X_{j} \beta-$ $\alpha p_{j}^{c o p}+\xi_{j}$, which depends on observed product characteristics $X_{j}$, copayment price $p_{j}^{c o p}$ and product characteristics $\xi_{j}$ (that are unobserved to the econometrician).

The nesting structure is reflected in $d_{j g}$, a dummy equal to one if product $j$ belongs to the set of products $J$ in nest $g\left(J_{g}\right)$ and zero otherwise. $\zeta_{i g}$ is common to all products in nest $g$ and its distribution depends on the nesting parameter $\sigma$. The random utility term $\varepsilon_{i j}$ represents unobserved consumer-specific heterogeneity. Each $\varepsilon_{i j}$ is assumed to be identically, independently distributed extreme value across consumers and products.

\footnotetext{
${ }^{12}$ Consumers can choose a product that belongs to a different substitution group only after consulting the practitioner. I allow for this possibility in my estimation.
} 
Cardell (1997) shows that if $\varepsilon_{i j}$ is i.i.d. extreme value, then $\zeta_{i g}+(1-\sigma) \varepsilon_{i j}$ is also an extreme value random variable.

The nesting parameter measures correlation of consumer choices between substitution groups. Products are considered closer substitutes the closer $\sigma$ gets to one. If $\sigma=1$ the model reduces to a simple logit model where there is perfect substitutability of products between nests. However, if $\sigma=0$ there is no substitution across nests. For the nested logit to be consistent with random-utility maximization, the estimated value for $\sigma$ must lie between 0 and 1 (McFadden, 1978).

The model also includes one nest that is explicitly modeled as the "outside" option. This option allows consumers with high cholesterol to be treated with drugs other than statins, or with lifestyle changes only, such as more sport and a low-fat diet. In the absence of the outside option, a change in the prices of the inside goods, statins, will not have an effect on aggregate output. The price of the single product in the outside option is assumed not to be set in response to the prices of the inside goods and its mean utility is normalized to zero $\left(\delta_{0} \equiv 0\right)$.

If each consumer selects the product that provides them with the highest utility and using the distributional assumptions on $\varepsilon_{i j}$, Berry (1994) shows how to solve for mean utility levels as a function of observed market shares. The market share of product $j s_{j}$ can be decomposed as follows:

$$
s_{j}(\delta, \sigma)=s_{j \mid g}(\delta, \sigma) s_{g}(\delta, \sigma),
$$

where $s_{j \mid g}$ is the share of product $j$ in nest $g$ and $s_{g}$ is the share of nest $g$ in the market. Following Berry (1994), these terms are:

$$
s_{j \mid g}(\delta, \sigma)=\frac{\exp \left(\delta_{j} /(1-\sigma)\right)}{D_{g}} \text { and } s_{g}(\delta, \sigma)=\frac{D_{g}^{(1-\sigma)}}{\sum_{g} D_{g}^{(1-\sigma))}}
$$

where $D_{g}$ is:

$$
D_{g} \equiv \sum_{j \in J_{g}} \exp \left(\delta_{j} /(1-\sigma)\right)
$$

The nest containing the outside good has only one element $\left(D_{o}=1\right)$, thus the market share of the outside good is:

$$
s_{o}(\delta, \sigma)=\frac{1}{\sum_{g} D_{g}^{(1-\sigma)}}
$$


Finally, solving for mean utility levels the linear equation to be estimated is:

$$
\ln \left(s_{j}\right)-\ln \left(s_{o}\right)=X_{j} \beta-\alpha p_{j}^{c o p}+\sigma \ln \left(s_{j \mid g}\right)+\xi_{j}
$$

The variables included in the vector of observed product characteristics are the strength, package size, a dummy variable indicating if the product is on-patent and the number of products in the same nest. I further include firm and time period dummy variables in the specification. The key parameters are the coefficient on price $\alpha$ and the nesting parameter $\sigma$. These parameters will determine elasticities of demand and thereby influence the substitution patterns of consumers and the price setting of firms. My prior is that $\alpha$ has a negative sign such that higher prices are associated with a decrease in mean utility. The nesting parameter $\sigma$ should lie between 0 and 1 to be consistent with random-utility maximization.

\subsubsection{Instrumental Variables}

Endogeneity of prices and the conditional share $\left(p_{j}^{c o p}\right.$ and $\left.s_{j \mid g}\right)$ are caused by heterogeneity in preferences affecting the demand substitution patterns and product level attributes that are known to firms and patients but unobserved by the researcher. As a way to correct for this endogeneity I use instrumental variables that are commonly used in the literature (Berry et al. (1995), Nevo (2001) and more recently Armstrong (2016), Berry and Haile (2014), and Reynaert and Verboven (2014)). These are variables that generate exogenous variation in the choice sets, such as the number of rival firm products, or functions of other products' attributes, such as the sum of characteristics of rival firms. The intuition is that characteristics of product $k$ are not included in the utility function for product $j$ but are correlated with the price and conditional shares of product $j$ only through the markup in the first-order conditions of the profit maximizing firm in oligopolistic competition. In the same way, optimal pricing depends on the characteristics and prices of all products offered, for which higher order polynomials of a firms' own products' characteristics have been suggested as valid instruments. Additional instruments are cost shifters or proxies for costs. I use the average price of products from the same firm in other substitution groups which captures supply shocks that affect all products from the same firm. 


\subsubsection{Market Size and the Outside Good}

Longstanding elevated levels of cholesterol in the blood induce the formation of plaque in the arteries causing narrowing or even blockage of arteries. This condition is asymptomatic and can go undetected for a long period of time, generating life-threatening problems such as heart attacks or strokes. Total market size includes consumption by both consumers in treatment and potential consumers with high cholesterol levels. In a similar way as Dunn (2012) or Ching et al. (2015) I use different sources to determine total market size. The first step is to define the fraction of the population with elevated levels of cholesterol. Guidelines recommend a healthy adult to have less than 5 millimoles of total cholesterol per liter of blood $(\mathrm{mmol} / \mathrm{L})$ and less than $3 \mathrm{mmol} / \mathrm{L}$ of low-density lipoprotein cholesterol. According to the Danish Association of Heart Patients (Madsen and Videbæk, 2004) and the Danish Institute for Rational Pharmacotherapy (IRF, 2006) around 60 percent of the Danish population between 40 and 80 years of age exceed these thresholds. This estimate is in line with a report from the World Health Organization (Roth et al., 2011) that shows disease prevalence statistics for countries similar to Denmark, where the percentage of total population aged 40-79 years with high levels of cholesterol lies between 35 percent and 61 percent.

Second, total consumption of statins by consumers in treatment is obtained from the Danish Health Data and Disease Control Institute (www.medstat.dk). I assume that if potential consumers were prescribed with statins they would consume the same dosage as the average actual consumer. The sum of actual consumption and hypothetical consumption by potential consumers gives total market size.

\subsubsection{Price Elasticities}

Finally, the price paid by consumers $\left(p^{c o p}\right)$ is the relevant price to calculate the associated elasticities. Using $\alpha$ and $\sigma$ from the demand estimation the own price elasticity for product $j$ in a nested logit is:

$$
\eta_{j j}=\frac{\partial s_{j}}{\partial p_{j}^{c o p}} \frac{p_{j}^{c o p}}{s_{j}}=-\alpha \frac{1}{(1-\sigma)} p_{j}^{c o p}\left[1-\sigma s_{j \mid g}-(1-\sigma) s_{j}\right] .
$$

Cross-price elasticities are expected to be smaller if the products are considered less substitutable. If product $j$ and product $k$ are in the same substitution group their respec- 
tive cross-price elasticity is:

$$
\eta_{j k}=\frac{\partial s_{j}}{\partial p_{k}^{c o p}} \frac{p_{k}^{c o p}}{s_{j}}=\alpha \frac{1}{(1-\sigma)} p_{k}^{c o p}\left[\sigma s_{k \mid g}+(1-\sigma) s_{k}\right]
$$

If product $j$ and product $l$ are not in the same substitution group, the cross-price elasticity is:

$$
\eta_{j l}=\frac{\partial s_{j}}{\partial p_{l}^{c o p}} \frac{p_{l}^{c o p}}{s_{j}}=\alpha p_{l}^{c o p} s_{l}
$$

\subsection{Supply Estimation}

On the supply side of the market there are multiproduct firms that are free to choose their pharmacy purchase price $\left(p^{f}\right)$. Assuming that prices are set in a Bertrand-Nash equilibrium, the profit-maximization conditions can be used to recover markups and marginal cost of production.

Each firm $f$, with $f=1, \ldots, F$, produces some subset $\vartheta_{f}$ of the $J$ products. The profit function of firm $f$ can then be written as:

$$
\Pi_{f}=\sum_{j \in \vartheta_{f}}\left(p_{j}^{f}-c_{j}\right) s_{j} M-K
$$

Where $p_{j}^{f}, c_{j}$, and $s_{j}$ are product $j$ 's respective pharmacy purchase price, marginal cost, and market share. $M$ is total market size including consumption from actual and potential consumers, and $K$ are the firm's fixed cost.

The first order condition for product $j$ is:

$$
\frac{\partial \pi_{j}}{\partial p_{j}^{f}}=M\left(s_{j}+\sum_{h \in \vartheta_{f}}\left(p_{h}^{f}-c_{h}\right) \frac{\partial s_{h}}{\partial p_{j}^{f}}\right)=0
$$

Each firm sets prices for each product considering the price of all of its other products. The set of $J$ first order conditions characterizes equilibrium prices and can be rewritten in vector form as $S\left(p^{c o p}, x, \xi\right)-\Delta\left(p^{c o p}, x, \xi\right)(P-C)=0$, where $S$ is the vector of shares, $\Delta$ is a $J \times J$ matrix with $\Delta=-\partial s_{h} / \partial p_{j}^{f}$ if $h$ and $j$ are produced by the same firm and $\Delta=0$ otherwise, $P$ is the vector of pharmacy purchase prices $\left(p^{f}\right)$, and $C$ a vector of marginal cost. Because the shares are functions of copayment prices, I use equation (1) and (2) to express everything in terms of pharmacy purchase price, taking into account that prescription fees, pharmacy markups as well as the reference price are exogenously 
given. Explicitly using reference prices, which in some cases can be the average EU price, partially controls for prices in another countries. This is novel in the literature and relevant because firms, in particular original firms, optimize over all interconnected markets. To capture this behaviour is challenging because it is difficult to obtain reliable data on the quantity of a product and price information is almost never publicly available. Another difficulty is that national-level price regulation limits the ability of the firm to set prices freely. Germany, for example, uses tender procedures and rebate contracts to obtain lower prices. Some southern European countries that serve as a source of parallel trade negotiate prices directly with pharmaceutical companies. By using rich information on price setting in Denmark and I can partially control for prices from other surrounding countries. Finally, the $J$ pricing equations can be expressed as marginal cost and markup, where the term $\Delta^{-1} S$ is a measured of predicted markups:

$$
P=C+\Delta^{-1} S
$$

\subsection{Counterfactual Calculation}

Removing parallel importers from the market affects the market participants in different ways. Firms face less competition, which is associated with an increase in prices. In addition to to facing higher expenditures due to the increase in prices, consumers are confronted with less variety. Consumers that consumed parallel imports substitute towards generics, original products or to the outside option. Finally, the effect of a ban of parallel imports on governmental expenditures depends on the magnitude of changes in prices and the subsequent choices available to consumers. If, for example, former buyers of parallel imports choose original products whose prices then rise, then government expenditures would most likely increase, since the prices of original products are on average higher than the prices of parallel imports even in the absence of the prohibition.

To calculate the new equilibrium I use the following three equations. First, I follow the Danish rules and regulations and use equation (1) and (2) to obtain the counterfactual copayment prices $^{13}$ as follows:

$$
p_{j_{\text {counter }}}^{\text {cop }}=\mu p_{j_{\text {counter }}}^{f}+k-0.8 * p_{j}^{r} .
$$

\footnotetext{
${ }^{13}$ The reference price is updated as long as the counterfactual pharmacy retail price remains below the European average price. Otherwise it is set equal to the prevailing average European price.
} 
Second, eliminating parallel imports does not affect consumer tastes, therefore I use equation (4) to obtain counterfactual shares for each product:

$$
s_{j_{\text {counter }}}\left(\delta_{\text {counter }}, \sigma\right)=\frac{\exp \left(\delta_{j_{\text {counter }}} /(1-\sigma)\right)}{D_{g}} \frac{D_{g}^{(1-\sigma)}}{\sum_{g} D_{g}^{(1-\sigma))}},
$$

where $\delta_{j_{\text {counter }}}=X_{j} \beta-\alpha p_{j_{\text {counter }}}^{c o p}+\xi_{j}$. Finally, removing parallel imports does not affect the marginal cost of production of the remaining firms. ${ }^{14}$ Using the same BertrandNash equilibrium assumptions for the price setting behavior of the firms, I calculate counterfactual pharmacy purchase prices using the marginal cost implied by the demand estimates as follows:

$$
P_{\text {counter }}^{f}=C+\Delta_{\text {counter }}^{-1} S_{\text {counter }}
$$

Solving equations (8), (9), and (10) simultaneously yields the counterfactual market equilibrium prices and shares.

\subsection{Consumer Surplus and Welfare}

Consumer surplus is (Small and Rosen 1981):

$$
C S=\frac{1}{\alpha} M \ln \left[1+\sum_{g=1}^{G}\left(\sum_{j \in G_{g}} \exp ^{\delta_{j} /(1-\sigma)}\right)^{(1-\sigma)}\right]
$$

I use equation (11) to calculate yearly consumer surplus with the real data and with the counterfactual data. The difference $C S_{\text {real }}-C S_{\text {counterfactual }}$ measures the effects on consumer surplus generated by prohibiting parallel imports. This measure not only accounts for possible harm induced by price increases, but, because it takes consumers' preferences into consideration, it also captures losses generated by reducing the market variety.

Finally, I define total welfare as the sum of consumer surplus and firm profits. The difference between real total welfare and counterfactual total welfare mirrors the changes in total welfare from a prohibition on parallel trade. This measure of welfare is static and limited to the effects that this ban has on Denmark, an importing country.

\footnotetext{
${ }^{14}$ Marginal cost is assumed to be constant, i.e. the increment in cost of producing an additional unit at each level of production does not change by removing parallel traders. However, I do allow for marginal cost to change over time.
} 


\section{Results}

This section reports three sets of empirical findings. First, it presents estimates of the utility parameters and the implied elasticities. Second, it reports cost estimates for the different firm types. Third, this section provides policy implications from a counterfactual analysis.

\subsection{Demand}

Estimating the demand side in (5) yields the empirical counterparts of the utility parameters and the substitution parameters. As expected the coefficient on copayment price is negative and the nesting parameter is positive.

Estimates are provided in Table 4. The estimated OLS coefficient on copayment price $\alpha$ is close to zero $(-0.053)$. When controlling for endogeneity the estimate remains negative, as expected. This means that a higher copayment price reduces consumers' mean utility. Specifically the IV - nested logit estimate of $\alpha$ is -0.832 . These estimates are in line with previous findings: Dunn (2012) finds a price coefficient of -1.61 for anti-cholesterol drugs based on US data covering the period 1996 to 2007. Similarly, Branstetter et al. (2016) obtain a price coefficient of -0.30 for the market of hypertension drugs in the United States between 1997 and 2008.

The OLS estimate of the nesting parameter $\sigma$ is 0.803 , which shows a relatively high degree of substitution across different product groups. The degree of substitution is lower when controlling for endogeneity. In this case the estimate of $\sigma$ is 0.315 . Both estimates lie between zero and one (which is consistent with random-utility maximization) and are slightly higher than the value 0.24 reported in Dutta (2011).

The estimation of the utility parameters yields further insights. First, products with less strength $(-0.807)$ and more pills per package (0.018) are associated with higher market shares. The coefficient on products in groups with patent protection is positive (1.697), while the coefficient on the number of products in each substitution group is negative $(-0.212)$, suggesting that a less competitive environment has a positive impact on market shares. Second, the firms dummy coefficients indicate that consumers have a strong preferences for original firms, followed by parallel importers.

Correct identification of the demand parameters are crucial for determining substitution patterns that will influence the counterfactual calculations. F-statistics from the first 
stage regression are reported at the bottom of Table 4. The first-stage F-statistic suggests that the instruments are valid and have enough power to correct for endogeneity.

A caveat in my model and in many others that have access to market-level data only is the potential selection bias caused by endogenous entry. Suppose that generic firms only enter markets where high demand is expected. Entry would generate a price decrease and an increase in the quantity supplied. If the model does not correct for endogenous entry, demand in that market would appear to be more price sensitive. Translated to this model, the copayment price coefficient $(\alpha)$ would be higher than it should be and the results are more likely to be overestimated. But in the case of statins, during the time period I observe there is a feature that might mitigate this bias. Four out of six molecules, including the two largest markets in terms of sales and revenues (Simvastatin - C10AA01 and Atorvastatin - C10AA05) are very stable and do not experience entry or exit. In the other two markets the patent expired and generics entered the market, but parallel importers were already active in those markets even before the generics were allowed to enter.

The empirical insights regarding the substitution patterns are summarized in Table 5. It presents the mean own and cross-price elasticities of demand associated with the coefficient estimated from the IV - nested logit and shows that the own-price elasticities are negative and the cross-price elasticities are positive. Part A reports the average elasticities for all products. The mean own-price elasticity is -3.608 and is very similar to the obtained result in Dunn (2012) of -3.11. The results on cross-price elasticities are, as expected, small and much lower if products belong to different substitution groups. Part B of Table 5 reports average elasticities for products in each molecule group. Part C of the table reports elasticities for products in each type of firm. Original firms and parallel importers, both of which charge higher prices, have higher elasticities than generics. The lower own-price elasticity of generics supports the important role of pharmacy incentives (in the Danish case through the rules on generic substitution) (Brekke et al., 2013). Finally, Part D summarizes the results for products off-patent and on-patent. Mean ownprice elasticities are higher if the product is off-patent, which is expected to be a more competitive segment. 


\subsection{Supply}

This section uses the results from the demand side to estimate the supply side in (7). The estimated average marginal cost of production for a unit of DDD is DKK 5.28 (see Table 6). This cost estimate is below the average pharmacy purchase price of DKK 5.93 (reported in Table 2), implying an average unit margin of DKK 0.65 or 21 percent of the pharmacy purchase price. Table 6 also reports average production cost and markups at the molecule level, for all three types of firm and by patent status. All marginal costs are positive and of comparable size. This is evidence that price differences across molecules are the result of differences in markups rather than differences in marginal cost of production. The markups are slightly lower than the price-cost margins reported by Dubois and Lasio (2014) and Brekke et al.(2013). But they are in line with their findings that original firms have lower margins than generic firms. This is attributed to the lower cost of production of generics in comparison to original products.

Interestingly, the table shows that markups differ by the patent status of the molecules. Markups are lower for off-patent molecules and higher for on-patent molecules in absolute values. This result nicely illustrates that competition from generics erodes unit markups, especially for original firms: the on-patent molecules generate higher markups than the off-patent molecules because there is only competition due to parallel imports but not from generics (see Part D of Table 6).

Finally, unit markups for generics are relatively high if compared to other geographic markets. This can be attributed to the prevailing reimbursement system. The reference price for a given product is set exogenously at its pharmacy retail price if it is lower than the average EU price, creating an incentive for generic producers to cluster prices around the relatively high EU price. Consequently generics can achieve high unit markups. ${ }^{15}$

\subsection{The Impact of Parallel Trade}

To investigate the impact of parallel trade, I first calculate the counterfactual market equilibrium when parallel imported products are eliminated from the consumers' choice set. Next, I compare the market outcome when parallel imports are present to the counterfactual market outcome and derive policy implications.

\footnotetext{
${ }^{15}$ This argument is formalized by Kaiser et al. (2014).
} 


\subsubsection{Counterfactual Market Equilibrium}

Solving the system of equations in Section 5.3 yields the new market equilibrium prices and shares, which are used to find the new markups, firm profits, government expenditures and consumer expenditures. In this section I compare these results with their counterparts and summarize my findings due to parallel trade as follows. Eliminating parallel trade reduces average prices but results in higher prices for both original products and generic products. Intuitively, average prices decrease because parallel traded products - the cheaper alternative to the original product, but relatively more expensive than the generic alternative - are removed from the market. However, as competitive pressure decreases, this results in higher average prices for original products. Because prices are strategic complements, average prices for generic products increase as well. Furthermore, the copayment prices increase more for original products than for generics, which is caused by the prevailing reimbursement rules. On another dimension, prices in the off-patent sector (for original and generic products) increase more than they do in the on-patent market. This result provides evidence supporting the conjecture of Enemark et al. (2006) that, parallel importers of on-patent products do not put competitive pressure on original firms because the price-sensitive market segment that will switch to parallel imports is small or the parallel importer faces capacity constraints. These results on price effects due to parallel trade are reported in Table 7.

The changes in market share are linked to the substitution patterns. The results show that eliminating parallel trade leads to the substitution of parallel imported products with original products.

Original firms benefit from banning parallel imports while generic firms lose market share (see Table 8). Intuitively, these substitution patterns can be attributed to the strong preferences of consumers for original products and the fact that most parallel imported products are likely to have been produced by original firms, whose perceived quality is presumably closer to original products than to generic products. Moreover, off-patent products gain substantially in market share from a prohibition on parallel imports.

The competitive pressure from generic products is also present when parallel trade is prohibited. As with the effects identified in the supply-side results, markups are lower for off-patent molecules and higher for on-patent molecules, even in the absence of parallel trade. Specifically, with a lack of competition of any kind in on-patent markets, origi- 
nal firms increase their markups substantially more than generic firms. The changes in markups are reported in Table 9.

Results on the impact of banning parallel trade on profits, government expenditures and consumers expenditures are presented in Table 10. Eliminating parallel trade generates an increase in profits and an increase in expenditures. The average profit for original firms in a 14-day period is DKK 0.57 million with the presence of parallel imports, this profit amounts to DKK 4.19 million after parallel imports are removed. On the contrary, the profits generated by generic firms decrease. Government expenditures and consumer expenditures follow the same path: expenditures of both groups on original products increase substantially more than their expenditures on generic products.

\subsubsection{Policy Implications}

The results from the counterfactual analysis with respect to consumer surplus and static welfare are summarized in Table 11. Eliminating parallel importers in Denmark reduces the consumer surplus and increases firm profits, leading to an overall decrease in welfare.

The consumer surplus decreases on average by DKK 111.41 million (around $\$ 18.2$ million or $€ 15$ million) when parallel importers are removed from the sample. ${ }^{16}$ The decrease in consumer surplus is driven by two factors. First, consumers have fewer products to choose from and since parallel imports are regarded as being closer to original products than generics, they substitute towards original products in the absence of the parallel imports. Second, a less competitive environment is associated with an increase in copayment price and so consumers of original products face higher prices. Finally, total welfare is given by the sum of consumer surplus and profits. The average welfare loss from a prohibition on parallel imports is DKK 54.9 million per year (around $\$ 8.9$ million or $€ 7.37$ million), a substantial amount for a market that generates around DKK 300 million per year.

Furthermore, removing parallel trade increases consumer expenditures as well as government expenditures. On average, yearly government expenditures increase by DKK 182.7 million (see Table 12). Yearly consumer expenditures increase on average by DKK 75 million: a figure that differs markedly from that of the consumer surplus. This shows that

\footnotetext{
${ }^{16}$ The observed data covers a period of three years, but only 2004 accounts for the whole 12 months, therefore each part of the table shows the average for each year. The yearly average at the bottom is constructed for any period of 12 months.
} 
using consumer expenditures only as a measure of welfare, as is done in previous studies, may result in an underestimation of the total welfare loss.

\section{Conclusions}

This paper analyzes the effects of parallel trade in the Danish market for statins. It develops a structural model of demand and supply and uses these estimates to simulate new market outcomes under a hypothetical ban of parallel imports. There are two key results from prohibiting parallel imports. The first set focuses on price effects, which differ along two dimensions: the type of firm and the patent protection status of the molecule. Eliminating parallel trade reduces average prices but results in higher prices for both original products and generic products. Furthermore, average prices for off-patent products decrease, while average prices for on-patent products are positively affected by excluding parallel imports. The second set of results reports the effects on market participants: i.e. firms, government and consumers. On average, firm profits increase, but the effect is positive for original firms and negative for generic firms. The consumer surplus decreases due to a decrease in product choice and an increase in expenditures. Moreover, government expenditures increase as a result of a prohibition on parallel trade. Finally, total welfare is defined as the sum of consumer surplus and profits. Eliminating parallel trade leads to an overall decrease in welfare. The results apply to Denmark and welfare implications are therefore to be interpreted as local and static.

My model takes into consideration consumer preferences, which determine substitution patterns, when estimating consumer surplus, as opposed to previous studies that use only consumer expenditures as a welfare measure. My results support the view that parallel trade generates significant savings to consumers and insurers. Furthermore, since the analysis is based on the rules and regulations applying in Denmark, expansion of these results to other geographical markets would require consideration of the relevant local regulations.

Finally, while beyond the scope of this paper, the long-term effects of parallel trade, particularly on incentives to innovate, remain a highly controversial and unresolved question. Because innovation is an important driver of consumer welfare and overall economic wellbeing, the subject constitutes an important issue for further research. 


\section{References}

Armstrong, TB. 2016. Large market asymptotics for differentiated product demand estimators with economic models of supply. Econometrica 84(5): 1964-1980.

Berry ST. 1994. Estimating discrete-choice models of product differentiation. The RAND Journal of Economics 25(2): 242-262.

Berry ST, Levinsohn J, Pakes A. 1995. Automobile prices in market equilibrium. Econometrica: Journal of the Econometric Society 63(4): 841-890.

Berry ST, Haile PA. 2014. Identification in differentiated products markets using market level data. Econometrica 82(5): 1749-1797.

Branstetter LG, Chatterjee C, Higgins MJ. 2016. Regulation and welfare: evidence from paragraph IV generic entry in the pharmaceutical industry. The RAND Journal of Economics 47(4): 857-890.

Brekke KR, Grasdal AL, Holmås TH. 2009. Regulation and Pricing of Pharmaceuticals: Reference Pricing or Price Cap Regulation. European Economic Review 53(2): 170185.

Brekke KR, Holmås TH, Straume OR. 2011. Reference Pricing, Competition, and Pharmaceutical Expenditures: Theory and Evidence from a Natural Experiment. Journal of Public Economics 95(7-8): 624-638.

Brekke KR, Holmås TH, Straume OR. 2013. Margins and Market Shares: Pharmacy incentives for generic substitution. European Economic Review 6: 116-131.

Brekke KR, Holmås TH, Straume OR. 2015. Price Regulation and Parallel Imports of Pharmaceuticals. Journal of Public Economics 129: 92-105.

Brekke KR, Königbauer I, Straume OR. 2007. Reference Pricing of Pharmaceuticals. Journal of Health Economics 26: 613-642.

Cardell NS. 1997. Variance Components Structures for the Extreme-Value and Logistic Distributions with Applications to Models of Heterogeneity. Econometric Theory 13(2): 185-213.

Ching AT. 2010a. A Dynamic Oligopoly Structural Model for the Prescription Drug Market after Patent Expiration. International Economic Review 51(4): 1175-1207. 
Ching AT. 2010b. Consumer Learning and Heterogeneity: Dynamics of Demand for Prescription Drugs After Patent Expiration. International Journal of Industrial Organization 28(6): 619-638.

Ching AT, Clark R, Horstmann I, Lim H. 2015. The effects of publicity on demand: The case of anti-cholesterol drugs. Marketing Science 35(1): 158-181.

Danzon PM. 1998. The Economics of Parallel Trade. Pharmacoeconomics 13(3): 293304.

Danzon PM, Chao LW. 2000. Cross-National Price Differences for Pharmaceuticals: How Large and Why?. Journal of Health Economics 19(2): 159-195.

Dubois P, Lasio L. 2014. Identifying industry margins with unobserved price constraints: structural estimation on pharmaceuticals. IDEI Working Paper(No.823).

Dubois P, Sæthre M. 2017. On the Role of Parallel Trade on Manufacturers and Retailers Profits in the Pharmaceutical Sector. mimeo

Dunn A. 2012. Drug innovations and welfare measures computed from market demand: The case of anti-cholesterol drugs. American Economic Journal: Applied Economics 4(3): $167-189$.

Duso T, Herr A, Suppliet M. 2014. The Welfare Impact Of Parallel Imports: A Structural Approach Applied To The German Market For Oral Anti-Diabetics. Health Economics 23: 1036-1057.

Dutta A. 2011. From free entry to patent protection: Welfare implications for the Indian pharmaceutical industry. The Review of Economics and Statistics 93(1): 160-178.

Enemark U, Pedersen KM, Sørensen J. 2006. The Economic Impact of Parallel Import of Pharmaceuticals. CAST-Centre for Applied Health Services Research and Technology Assessment: Odense.

Espín J, Rovira J, Olry de Labry A. 2011. WHO/HAI Project on Medicine Prices and Availability, Review Series on Pharmaceutical Pricing Policies and Interventions. Working Paper 1: External Reference Pricing

Ganslandt M, Maskus KE. 2004. Parallel imports and the pricing of pharmaceutical products: evidence from the European Union. Journal of Health Economics 23(5): $1035-1057$. 
Grabowski HR, Vernon JM. 1992. Brand loyalty, entry, and price competition in pharmaceuticals after the 1984 Drug Act. Journal of Law and Economics 35: 331-350.

Grossman GM, Lai ELC. 2008. Parallel imports and price controls. The RAND Journal of Economics 39(2): 378-402.

IRF Danish Institute for Rational Pharmacotherapy. 2006. Lipidscenkende behandling (Available from: http://www.irf.dk/dk/publikationer/rationel_farmakoterapi /maanedsblad/2006/lipidsaenkende_behandling.htm) [Accessed on 28 March 2014].

Kaiser U, Mendez SJ, Rønde T, Ullrich H. 2014. Regulation of pharmaceutical prices: evidence from a reference price reform in Denmark. Journal of Health Economics 36: $174-187$.

Kanavos P, Costa-Font J. 2005. Pharmaceutical parallel trade in Europe: stakeholder and competition effects. Economic Policy 20(44): 758-798.

Kyle MK. 2009. Parallel trade in pharmaceuticals: firm responses and competition policy. International Antitrust Law \& Policy: 339-358.

Kyle MK. 2011. Strategic responses to parallel trade. The BE Journal of Economic Analysis \& Policy 11(2): 1-34.

Kyle MK. 2016. Competition law, intellectual property, and the pharmaceutical sector. Antitrust Law Journal 81(1): 1-36.

Li C, Maskus KE. 2006. The impact of parallel imports on investments in cost-reducing research and development. Journal of International Economics 68(2): 443-455.

López-Casasnovas G, Puig-Junoy J. 2000. Review of the literature on reference pricing. Health policy 54(2): 87-123.

Madsen M, Videbæk J. 2004. Hjertestatistik - Heart Statistics 2004. Hjerteforeningen og Institut for Folkesundhed. (Available from: http://www.hjerteforeningen.dk) [Accessed on 24 June 2013].

McFadden D. 1978. Modelling the choice of residential location in A. Karlquist, L. Lundquist, F. Snickard and JJ Weilbull (eds). Spatial Interaction Theory and Planning Models: Amsterdam.

Nevo A. 2001. Measuring market power in the ready-to-eat cereal industry. Econometrica 69(2): $307-342$. 
Pavcnik N. 2002. Do pharmaceutical prices respond to potential patient out-of-pocket expenses?. The RAND Journal of Economics 33(3): 469-487.

Petrucci C. 2010. Parallel trade of pharmaceutical products: the ECJ finally speaksComment on GlaxoSmithKline. European Law Review 35(2): 275-286.

Reynaert M, Verboven F. 2014. Improving the performance of random coefficients demand models: the role of optimal instruments. Journal of Econometrics 179(1): 83-98.

Roth GA, Fihn SD, Mokdad AH, Aekplakorn W, Hasegawa T, Lim SS. 2011. High total serum cholesterol, medication coverage and therapeutic control: an analysis of national health examination survey data from eight countries. Bulletin of the World Health Organization 89(2): 92-101.

Scott Morton FM. 2000. Barriers to entry, brand advertising, and generic entry in the US pharmaceutical industry. International Journal of Industrial Organization 18(7): $1085-1104$.

Small KA, Rosen HS. 1981. Applied welfare economics with discrete choice models. Econometrica: Journal of the Econometric Society: 105-130.

Stern S. 1996. Market definition and the returns to innovation: Substitution patterns in pharmaceutical markets. Program on the Pharmaceutical Industry, Sloan School of Management, Massachusetts Institute of Technology.

Szymanski S, Valletti TM. 2006. Parallel trade, international exhaustion and intellectual property rights: a welfare analysis. The Journal of Industrial Economics 54(4): 499526.

Tsouloufas G. 2011. Limiting pharmaceutical parallel trade in the European Union: regulatory and economic justifications. European Law Review 36(3): 385-404.

Valletti TM. 2006. Differential pricing, parallel trade, and the incentive to invest. Journal of International Economics 70(1): 314-324.

Verboven F. 1996. International price discrimination in the European car market. The RAND Journal of Economics 27(2): 240-268. 


\section{Tables}

Table 1: Danish Market for Statins

\begin{tabular}{|c|c|c|c|c|c|c|}
\hline \multirow[t]{2}{*}{ ATC Code } & \multirow[t]{2}{*}{ Molecule } & \multirow[t]{2}{*}{ Brand name } & \multirow[t]{2}{*}{ Original Firm } & \multirow[t]{2}{*}{ Obs. } & \multicolumn{2}{|c|}{ Average Number of } \\
\hline & & & & & Firms & Products \\
\hline & & & & & $\begin{array}{r}\text { mean } \\
\text { (std. dev) }\end{array}$ & $\begin{array}{r}\text { mean } \\
\text { (std. dev) }\end{array}$ \\
\hline C10AA01 & Simvastatin & Zocor & MSD Sharp $\&$ Dohme & 3,323 & $\begin{array}{c}11.85 \\
(1.02)\end{array}$ & $\begin{array}{r}69.51 \\
(10.85)\end{array}$ \\
\hline C10AA02 & Lovastatin & Mevacor & MSD Sharp $\& 3$ Dohme & 829 & $\begin{array}{r}5.39 \\
(0.81)\end{array}$ & $\begin{array}{r}17.44 \\
(2.72)\end{array}$ \\
\hline C10AA03 & Pravastatin & Pravachol & Bristol-Myers Squibb & 766 & $\begin{array}{r}5.94 \\
(2.06)\end{array}$ & $\begin{array}{l}19.28 \\
(8.13)\end{array}$ \\
\hline C10AA04 & Fluvastatin & Lescol & Novartis & 490 & $\begin{array}{r}2.00 \\
(0.00)\end{array}$ & $\begin{array}{l}10.00 \\
(0.00)\end{array}$ \\
\hline C10AA05 & Atorvastatin & Lipitor & Pfizer & 611 & $\begin{array}{r}3.03 \\
(0.44)\end{array}$ & $\begin{array}{l}12.57 \\
(1.11)\end{array}$ \\
\hline C10AA07 & Rosuvastatin & Crestor & AstraZeneca & 369 & $\begin{array}{r}1.59 \\
(0.75)\end{array}$ & $\begin{array}{r}8.10 \\
(1.37)\end{array}$ \\
\hline All molecules & & & & 6,388 & $\begin{array}{r}19.71 \\
(1.96)\end{array}$ & $\begin{array}{r}130.76 \\
(7.05)\end{array}$ \\
\hline
\end{tabular}

Notes: Average number of firms and average number of products in each molecule group for a 14-day period. Products are characterized by the combination of molecule (5-level ATC code), strength, package size and firm. Standard deviation in parentheses 
Table 2: Average Prices

\begin{tabular}{|c|c|c|c|}
\hline & Pharmacy Purchase Price $\left(p^{f}\right)$ & Reference Price $\left(p^{r}\right)$ & Copayment Price $\left(p^{c o p}\right)$ \\
\hline & $\begin{array}{c}\text { mean } \\
\text { (std. dev) }\end{array}$ & $\begin{array}{c}\text { mean } \\
\text { (std. dev) }\end{array}$ & $\begin{array}{c}\text { mean } \\
\text { (std. dev) }\end{array}$ \\
\hline \multicolumn{4}{|l|}{ A. All Products } \\
\hline & $\begin{array}{c}5.93 \\
(4.53)\end{array}$ & $\begin{array}{c}7.31 \\
(5.34)\end{array}$ & $\begin{array}{c}3.21 \\
(4.42)\end{array}$ \\
\hline \multicolumn{4}{|l|}{ B. By ATC Code } \\
\hline C10AA01 & $\begin{array}{c}4.63 \\
(4.94)\end{array}$ & $\begin{array}{c}4.42 \\
(3.91)\end{array}$ & $\begin{array}{c}3.76 \\
(5.77)\end{array}$ \\
\hline C10AA02 & $\begin{array}{c}7.08 \\
(3.78)\end{array}$ & $\begin{array}{c}9.16 \\
(4.30)\end{array}$ & $\begin{array}{c}3.47 \\
(3.04)\end{array}$ \\
\hline C10AA03 & $\begin{array}{c}7.71 \\
(4.41)\end{array}$ & $\begin{array}{l}11.10 \\
(6.20)\end{array}$ & $\begin{array}{c}2.57 \\
(1.81)\end{array}$ \\
\hline C10AA04 & $\begin{array}{c}8.27 \\
(2.14)\end{array}$ & $\begin{array}{l}12.66 \\
(3.56)\end{array}$ & $\begin{array}{c}2.56 \\
(0.72)\end{array}$ \\
\hline C10AA05 & $\begin{array}{c}7.91 \\
(2.99)\end{array}$ & $\begin{array}{l}11.53 \\
(4.50)\end{array}$ & $\begin{array}{c}2.31 \\
(0.90)\end{array}$ \\
\hline C10AA07 & $\begin{array}{c}4.92 \\
(1.35)\end{array}$ & $\begin{array}{c}7.19 \\
(2.05)\end{array}$ & $\begin{array}{c}1.44 \\
(0.41)\end{array}$ \\
\hline \multicolumn{4}{|l|}{ C. By Firm Type } \\
\hline Original Firm & $\begin{array}{c}8.68 \\
(3.62)\end{array}$ & $\begin{array}{l}10.35 \\
(4.91)\end{array}$ & $\begin{array}{c}4.63 \\
(4.84)\end{array}$ \\
\hline Generic Firm & $\begin{array}{c}2.62 \\
(2.03)\end{array}$ & $\begin{array}{c}3.86 \\
(2.32)\end{array}$ & $\begin{array}{c}1.31 \\
(1.77)\end{array}$ \\
\hline Parallel Importer & $\begin{array}{c}7.64 \\
(5.04)\end{array}$ & $\begin{array}{c}8.92 \\
(6.07)\end{array}$ & $\begin{array}{c}4.4 \\
(5.50)\end{array}$ \\
\hline \multicolumn{4}{|c|}{ D. By Patent Status } \\
\hline Off-Patent & $\begin{array}{c}5.69 \\
(4.78)\end{array}$ & $\begin{array}{c}6.67 \\
(5.31)\end{array}$ & $\begin{array}{c}3.46 \\
(4.82)\end{array}$ \\
\hline On-Patent & $\begin{array}{c}7.00 \\
(2.85)\end{array}$ & $\begin{array}{l}10.29 \\
(4.34)\end{array}$ & $\begin{array}{c}2.06 \\
(0.87)\end{array}$ \\
\hline
\end{tabular}

Notes: Fortnightly average prices for a defined daily dose in Danish krones. All figures deflated using consumer prices index with June 2005 as basis. $p^{f}$ is the pharmacy purchase price, $p^{r}$ is the reference price, and $p^{c o p}=p^{c}-0.8 * p^{r}$ is the copayment price. The results are summarized as follows: A. All products, B. Products in the same ATC code, C. Products from the same firm type, and D. Products on-patent and off-patent. Exchange rates in June 2005: DKK $1=\$ 0.1634=€ 0.1343$. Standard deviation in parentheses. 
Table 3: Average Sales, Average Revenues, and Average Expenditures

\begin{tabular}{|c|c|c|c|c|}
\hline & \multirow[t]{2}{*}{ Sales } & \multirow[t]{2}{*}{ Revenues } & \multicolumn{2}{|c|}{ Expenditures } \\
\hline & & & Government & Consumers \\
\hline & $\begin{array}{c}\text { mean } \\
\text { (std. dev) }\end{array}$ & $\begin{array}{c}\text { mean } \\
\text { (std. dev) }\end{array}$ & $\begin{array}{c}\text { mean } \\
\text { (std. dev) }\end{array}$ & $\begin{array}{c}\text { mean } \\
\text { (std. dev) }\end{array}$ \\
\hline \multicolumn{5}{|l|}{ A. All Products } \\
\hline & $\begin{array}{l}2,446.127 \\
(520.621)\end{array}$ & $\begin{array}{c}9.139 \\
(1.891)\end{array}$ & $\begin{array}{l}10.342 \\
(2.075)\end{array}$ & $\begin{array}{c}3.315 \\
(0.627)\end{array}$ \\
\hline \multicolumn{5}{|l|}{ B. By ATC Code } \\
\hline C10AA01 & $\begin{array}{l}1,669.324 \\
(550.280)\end{array}$ & $\begin{array}{c}2.516 \\
(0.498)\end{array}$ & $\begin{array}{c}2.729 \\
(0.579)\end{array}$ & $\begin{array}{c}1.344 \\
(0.224)\end{array}$ \\
\hline C10AA02 & $\begin{array}{l}24.420 \\
(4.845)\end{array}$ & $\begin{array}{c}0.186 \\
(0.103)\end{array}$ & $\begin{array}{c}0.188 \\
(0.123)\end{array}$ & $\begin{array}{c}0.087 \\
(0.037)\end{array}$ \\
\hline C10AA03 & $\begin{array}{l}182.748 \\
(45.749)\end{array}$ & $\begin{array}{c}1.554 \\
(0.803)\end{array}$ & $\begin{array}{c}1.776 \\
(0.951)\end{array}$ & $\begin{array}{c}0.472 \\
(0.202)\end{array}$ \\
\hline C10AA04 & $\begin{array}{l}23.021 \\
(4.910)\end{array}$ & $\begin{array}{c}0.178 \\
(0.041)\end{array}$ & $\begin{array}{c}0.211 \\
(0.049)\end{array}$ & $\begin{array}{c}0.053 \\
(0.012)\end{array}$ \\
\hline C10AA05 & $\begin{array}{l}470.609 \\
(76.914)\end{array}$ & $\begin{array}{c}4.312 \\
(0.897)\end{array}$ & $\begin{array}{c}4.982 \\
(1.052)\end{array}$ & $\begin{array}{c}1.246 \\
(0.263)\end{array}$ \\
\hline C10AA07 & $\begin{array}{c}79.241 \\
(33.288)\end{array}$ & $\begin{array}{c}0.409 \\
(0.166)\end{array}$ & $\begin{array}{c}0.477 \\
(0.191)\end{array}$ & $\begin{array}{c}0.119 \\
(0.048)\end{array}$ \\
\hline \multicolumn{5}{|l|}{ C. By Firm Type } \\
\hline Original Firms & $\begin{array}{c}694.424 \\
(167.741)\end{array}$ & $\begin{array}{c}6.176 \\
(1.793)\end{array}$ & $\begin{array}{c}6.615 \\
(2.018)\end{array}$ & $\begin{array}{c}2.325 \\
(0.593)\end{array}$ \\
\hline Generic Firms & $\begin{array}{l}1,498.947 \\
(633.574)\end{array}$ & $\begin{array}{c}1.639 \\
(0.527)\end{array}$ & $\begin{array}{c}2.182 \\
(0.691)\end{array}$ & $\begin{array}{c}0.584 \\
(0.176)\end{array}$ \\
\hline Parallel Imports & $\begin{array}{c}252.757 \\
(149.244)\end{array}$ & $\begin{array}{c}1.324 \\
(0.100)\end{array}$ & $\begin{array}{c}1.545 \\
(0.444)\end{array}$ & $\begin{array}{c}0.406 \\
(0.141)\end{array}$ \\
\hline \multicolumn{5}{|c|}{ D. By Patent Status } \\
\hline Off-Patent & $\begin{array}{l}1,890.991 \\
(525.779)\end{array}$ & $\begin{array}{c}4.367 \\
(1.165)\end{array}$ & $\begin{array}{c}4.823 \\
(1.238)\end{array}$ & $\begin{array}{c}1.935 \\
(0.411)\end{array}$ \\
\hline On-Patent & $\begin{array}{l}555.136 \\
(72.161)\end{array}$ & $\begin{array}{c}4.772 \\
(0.868)\end{array}$ & $\begin{array}{c}5.519 \\
(1.020)\end{array}$ & $\begin{array}{c}1.380 \\
(0.255)\end{array}$ \\
\hline
\end{tabular}

Notes: Sales are fortnightly averages in 1,000 defined daily dosages. Revenues and expenditures are fortnightly averages in million Danish krones. The results are summarized as follows: A. All products, B. Products in the same ATC code, C. Products from the same firm type, and D. Products on-patent and off-patent. Exchange rates in June 2005: DKK $1=\$ 0.1634=€ 0.1343$. Standard deviation in parentheses. 
Table 4: Demand Estimation

\begin{tabular}{|c|c|c|c|c|}
\hline & \multicolumn{2}{|c|}{ OLS - Nested Logit } & \multicolumn{2}{|c|}{ IV - Nested Logit } \\
\hline & Coef. & (Std. Error) & Coef. & (Std. Error) \\
\hline Copayment price & $-0.053^{* * *}$ & $(0.004)$ & $-0.831^{* * *}$ & $(0.051)$ \\
\hline Conditional share & $0.880^{* * *}$ & $(0.007)$ & $0.315^{*}$ & $(0.123)$ \\
\hline Strength in ddd & $0.347^{* * *}$ & $(0.022)$ & $-0.807^{* * *}$ & $(0.067)$ \\
\hline Package size & $0.024^{* * *}$ & $(0.0004)$ & $0.018^{* * *}$ & $(0.001)$ \\
\hline On-Patent & $0.979 * * *$ & $(0.064)$ & $1.697^{* * *}$ & $(0.119)$ \\
\hline No. prod. in nest & $0.239^{* * *}$ & $(0.005)$ & $-0.212^{* * *}$ & $(0.051)$ \\
\hline Constant & $-11.416^{* * *}$ & $(0.609)$ & $-10.669^{* * *}$ & $(0.952)$ \\
\hline
\end{tabular}

Firm Dummy Variables

Original Firms

\begin{tabular}{|c|c|c|c|c|}
\hline AstraZeneca & 0.589 & $(0.609)$ & $2.813^{* *}$ & $(0.939)$ \\
\hline Bristol-Myers Squibb & $2.601^{* * *}$ & $(0.611)$ & $6.183^{* * *}$ & $(0.957)$ \\
\hline MSD Sharp \& Dohme & $1.897^{* *}$ & $(0.609)$ & $9.207^{* * *}$ & $(1.036)$ \\
\hline Novartis & 0.415 & $(0.610)$ & $2.244^{*}$ & $(0.940)$ \\
\hline Pfizer & $2.147^{* * *}$ & $(0.611)$ & $5.056^{* * *}$ & $(0.947)$ \\
\hline \multicolumn{5}{|l|}{ Generic Firms } \\
\hline 1A Farma & $1.768^{* *}$ & $(0.611)$ & $2.614^{*}$ & $(1.024)$ \\
\hline Actavis & 0.21 & $(0.612)$ & 0.742 & $(0.937)$ \\
\hline Alpharma & $2.186^{* * *}$ & $(0.610)$ & $2.084^{*}$ & $(0.942)$ \\
\hline Alternova & $1.401^{*}$ & $(0.608)$ & 1.336 & $(0.934)$ \\
\hline Arrow & 1.002 & $(0.632)$ & $4.330^{* * *}$ & $(0.947)$ \\
\hline Durascan & $1.987 * *$ & $(0.609)$ & 0.663 & $(0.952)$ \\
\hline Genthon & $1.283^{*}$ & $(0.617)$ & 1.066 & $(0.971)$ \\
\hline Gevita & $1.702^{* *}$ & $(0.612)$ & 0.634 & $(0.956)$ \\
\hline Hexal & $2.052^{* * *}$ & $(0.609)$ & $2.143^{*}$ & $(0.947)$ \\
\hline Ranbaxy & 1.186 & $(0.620)$ & 0.915 & $(0.964)$ \\
\hline Ratiopharm & $1.198^{*}$ & $(0.609)$ & 0.349 & $(0.959)$ \\
\hline Sandoz & $1.270^{*}$ & $(0.611)$ & -0.073 & $(0.970)$ \\
\hline \multicolumn{5}{|l|}{ Parallel Importers } \\
\hline Copyfarm & $2.013^{* *}$ & $(0.622)$ & 0.618 & $(0.984)$ \\
\hline EuroPharma & $1.261^{*}$ & $(0.616)$ & 1.941 & $(0.998)$ \\
\hline Orifarm & $1.454^{*}$ & $(0.609)$ & $4.207^{* * *}$ & $(0.968)$ \\
\hline Paranova & $1.230^{*}$ & $(0.609)$ & $2.237^{*}$ & $(0.964)$ \\
\hline PharmaCoDane & $1.411^{*}$ & $(0.608)$ & $4.729^{* * *}$ & $(1.065)$ \\
\hline Recept Pharma & $1.230^{*}$ & $(0.621)$ & 1.138 & $(0.957)$ \\
\hline Stada & 0.082 & $(0.612)$ & 0.522 & $(0.979)$ \\
\hline \multicolumn{5}{|l|}{ First stage F-statistics: } \\
\hline Copayment price $($ Prob $>$ F) & & & 85.38 & $(0.000)$ \\
\hline Conditional share $($ Prob $>$ F) & & & 35.57 & $(0.000)$ \\
\hline
\end{tabular}

Notes: Table 4 reports OLS and IV - nested logit estimates of equation (5). The dependent variable is $\ln \left(s_{j}\right)-\ln \left(s_{o}\right)$. The number of observations is 6,388 . The specification also includes time period dummy variables. The reference category for firm dummy variables is the parallel importer Universal Pharma. Robust standard errors in parenthesis. ***, ** and * indicate statistical significance at the one, five, and ten percent level. The instruments for the IV - nested logit are: the average price of products from the same firm in other substitution groups, the number of products of rival firms, the sum of characteristics of rival firms, and squares of own products' characteristics. 
Table 5: Average Own- and Cross-Price Elasticities of Demand

\begin{tabular}{|c|c|c|c|}
\hline & \multirow[t]{2}{*}{ Own-price elasticities } & \multicolumn{2}{|c|}{ Cross-price elasticities } \\
\hline & & Same nest & Different nest \\
\hline & $\begin{array}{c}\text { mean } \\
\text { (std. dev) }\end{array}$ & $\begin{array}{c}\text { mean } \\
\text { (std. dev) }\end{array}$ & $\begin{array}{c}\text { mean } \\
\text { (std. dev) }\end{array}$ \\
\hline \multicolumn{4}{|l|}{ A. All Products } \\
\hline & $\begin{array}{l}-3.608 \\
(5.263)\end{array}$ & $\begin{array}{c}0.179 \\
(0.245)\end{array}$ & $\begin{array}{c}0.0014 \\
(0.0004)\end{array}$ \\
\hline \multicolumn{4}{|l|}{ B. By ATC Code } \\
\hline C10AA01 & $\begin{array}{l}-4.398 \\
(6.878)\end{array}$ & $\begin{array}{c}0.074 \\
(0.193)\end{array}$ & $\begin{array}{c}0.0015 \\
(0.0004)\end{array}$ \\
\hline C10AA02 & $\begin{array}{l}-3.816 \\
(3.380)\end{array}$ & $\begin{array}{c}0.359 \\
(0.268)\end{array}$ & $\begin{array}{c}0.0014 \\
(0.0003)\end{array}$ \\
\hline C10AA03 & $\begin{array}{l}-2.854 \\
(2.077)\end{array}$ & $\begin{array}{c}0.191 \\
(0.137)\end{array}$ & $\begin{array}{c}0.0013 \\
(0.0003)\end{array}$ \\
\hline C10AA04 & $\begin{array}{l}-2.559 \\
(0.845)\end{array}$ & $\begin{array}{c}0.536 \\
(0.222)\end{array}$ & $\begin{array}{c}0.0014 \\
(0.0004)\end{array}$ \\
\hline C10AA05 & $\begin{array}{l}-2.190 \\
(0.732)\end{array}$ & $\begin{array}{c}0.256 \\
(0.132)\end{array}$ & $\begin{array}{c}0.0014 \\
(0.0003)\end{array}$ \\
\hline C10AA07 & $\begin{array}{l}-1.325 \\
(0.412)\end{array}$ & $\begin{array}{c}0.272 \\
(0.188)\end{array}$ & $\begin{array}{c}0.0014 \\
(0.0003)\end{array}$ \\
\hline \multicolumn{4}{|l|}{ C. By Firm Type } \\
\hline Original Firm & $\begin{array}{l}-5.043 \\
(5.906)\end{array}$ & $\begin{array}{c}0.273 \\
(0.259)\end{array}$ & $\begin{array}{c}0.0014 \\
(0.0004)\end{array}$ \\
\hline Generic Firm & $\begin{array}{l}-1.542 \\
(2.150)\end{array}$ & $\begin{array}{c}0.101 \\
(0.139)\end{array}$ & $\begin{array}{c}0.0014 \\
(0.0004)\end{array}$ \\
\hline Parallel Importer & $\begin{array}{l}-5.016 \\
(6.558)\end{array}$ & $\begin{array}{c}0.230 \\
(0.317)\end{array}$ & $\begin{array}{c}0.0015 \\
(0.0004)\end{array}$ \\
\hline \multicolumn{4}{|c|}{ D. By Patent Status } \\
\hline Off-patent & $\begin{array}{l}-3.962 \\
(5.727)\end{array}$ & $\begin{array}{c}0.162 \\
(0.245)\end{array}$ & $\begin{array}{c}0.0015 \\
(0.0004)\end{array}$ \\
\hline On-patent & $\begin{array}{l}-1.959 \\
(0.806)\end{array}$ & $\begin{array}{c}0.316 \\
(0.200)\end{array}$ & $\begin{array}{c}0.0014 \\
(0.0004)\end{array}$ \\
\hline
\end{tabular}

Notes: Table 5 reports mean own and cross-price elasticities of demand using the results from the IV - nested logit. The results are summarized as follows: A. All products, B. Products in the same ATC code, C. Products from the same firm type, and D. Products on-patent and off-patent. Standard deviation in parentheses. 
Table 6: Average Marginal Cost and Average Markups

\begin{tabular}{lcccc}
\hline & Marginal Cost & Marginal Cost in \% & Markups & Markups in \% \\
\hline & $\begin{array}{c}\text { mean } \\
\text { (std. dev) }\end{array}$ & $\begin{array}{c}\text { mean } \\
\text { (std. dev) }\end{array}$ & $\begin{array}{c}\text { mean } \\
\text { (std. dev) }\end{array}$ & $\begin{array}{c}\text { mean } \\
\text { (std. dev) }\end{array}$ \\
\hline A. All Products & & & & \\
& 5.277 & 79.082 & 0.648 & 20.918 \\
& $(4.486)$ & $(19.084)$ & $(0.137)$ & $(19.084)$ \\
\hline B. By ATC Code & & & & \\
C10AA01 & 4.038 & 71.886 & 0.588 & 28.114 \\
& $(4.906)$ & $(22.991)$ & $(0.135)$ & $(22.991)$ \\
C10AA02 & 6.428 & 87.015 & 0.651 & 12.985 \\
& $(3.760)$ & $(8.056)$ & $(0.074)$ & $(8.056)$ \\
C10AA03 & 7.052 & 85.888 & 0.655 & 14.112 \\
& $(4.395)$ & $(11.498)$ & $(0.087)$ & $(11.498)$ \\
C10AA04 & 7.537 & 90.279 & 0.732 & 9.721 \\
& $(2.184)$ & $(3.690)$ & $(0.076)$ & $(3.690)$ \\
C10AA05 & 7.141 & 88.423 & 0.774 & 11.577 \\
& $(2.957)$ & $(5.995)$ & $(0.110)$ & $(5.995)$ \\
C10AA07 & 4.080 & 81.603 & 0.840 & 18.397 \\
& $(1.324)$ & $(5.183)$ & $(0.058)$ & $(5.183)$
\end{tabular}

C. By Firm Type

$\begin{array}{lcccc}\text { Original Firm } & 7.940 & 88.943 & 0.745 & 11.057 \\ & (3.673) & (7.351) & (0.114) & (7.351) \\ \text { Generic Firm } & 2.035 & 68.068 & 0.584 & 31.932 \\ & (2.002) & (21.100) & (0.125) & (21.100) \\ \text { Parallel Importer } & 7.014 & 84.038 & 0.631 & 15.962 \\ & (4.992) & (16.904) & (0.114) & (16.904)\end{array}$

D. By Patent Status and Firm Type

\begin{tabular}{ccccc} 
Off-Patent & 5.077 & 77.496 & 0.617 & 22.504 \\
Original Firm & $(4.740)$ & $(20.476)$ & $(0.125)$ & $(20.476)$ \\
& 9.211 & 91.331 & 0.687 & 8.669 \\
Generic Firm & $(3.567)$ & $(6.856)$ & $(0.100)$ & $(6.856)$ \\
\multirow{2}{*}{ Parallel Importer } & 2.035 & 68.068 & 0.584 & 31.932 \\
& $(2.002)$ & $(21.100)$ & $(0.125)$ & $(21.100)$ \\
On-Patent & 7.200 & 83.298 & 0.623 & 16.702 \\
& $(5.321)$ & $(18.016)$ & $(0.118)$ & $(18.016)$ \\
Original Firm & 6.208 & 86.465 & 0.789 & 13.535 \\
\multirow{2}{*}{ Parallel Importer } & $(2.855)$ & $(6.465)$ & $(0.099)$ & $(6.465)$ \\
& 6.304 & 85.869 & 0.819 & 14.131 \\
& $(3.119)$ & $(6.809)$ & $(0.083)$ & $(6.809)$ \\
& 5.855 & 88.652 & 0.679 & 11.348 \\
& $(1.495)$ & $(4.362)$ & $(0.073)$ & $(4.362)$ \\
\hline
\end{tabular}

Notes: Table 6 reports average marginal cost and markups calculated from the first order conditions in equation (7) in Danish krones per defined daily dosse and marginal cost and markups as percentage of pharmacy purchase prices. The results are summarized as follows: A. All products, B. Products in the same ATC code, C. Products from the same firm type, and D. Products on-patent and off-patent. Exchange rates in June 2005: DKK $1=\$ 0.1634=€ 0.1343$. Standard deviation in parentheses 
Table 7: Average Change in Prices

\begin{tabular}{|c|c|c|c|c|c|c|c|c|c|}
\hline & \multicolumn{3}{|c|}{ Pharmacy purchase price $\left(p^{f}\right)$} & \multicolumn{3}{|c|}{ Reference price $\left(p^{r}\right)$} & \multicolumn{3}{|c|}{ Copayment price $\left(p^{c o p}\right)$} \\
\hline & real & counter. & $\begin{array}{c}\text { change } \\
\text { in } \%\end{array}$ & real & counter. & $\begin{array}{c}\text { change } \\
\text { in } \%\end{array}$ & real & counter. & $\begin{array}{c}\text { change } \\
\text { in } \%\end{array}$ \\
\hline & $\begin{array}{c}\text { mean } \\
(\mathrm{sd})\end{array}$ & $\begin{array}{c}\text { mean } \\
(\mathrm{sd})\end{array}$ & $\begin{array}{c}\text { mean } \\
\text { (sd) }\end{array}$ & $\begin{array}{c}\text { mean } \\
(\mathrm{sd})\end{array}$ & $\begin{array}{c}\text { mean } \\
(\mathrm{sd})\end{array}$ & $\begin{array}{c}\text { mean } \\
\text { (sd) }\end{array}$ & $\begin{array}{c}\text { mean } \\
(\mathrm{sd})\end{array}$ & $\begin{array}{c}\text { mean } \\
(\mathrm{sd})\end{array}$ & $\begin{array}{c}\text { mean } \\
(\mathrm{sd})\end{array}$ \\
\hline \multicolumn{10}{|l|}{ A. All Products } \\
\hline & $\begin{array}{c}5.92 \\
(4.53)\end{array}$ & $\begin{array}{c}5.33 \\
(4.17)\end{array}$ & -10.08 & $\begin{array}{c}7.31 \\
(5.34)\end{array}$ & $\begin{array}{c}6.70 \\
(4.88)\end{array}$ & -8.37 & $\begin{array}{c}3.21 \\
(4.42)\end{array}$ & $\begin{array}{c}2.84 \\
(3.93)\end{array}$ & -11.50 \\
\hline \multicolumn{10}{|l|}{ B. By ATC Code } \\
\hline C10AA01 & $\begin{array}{c}4.63 \\
(4.94)\end{array}$ & $\begin{array}{c}3.70 \\
(4.03)\end{array}$ & -19.96 & $\begin{array}{c}4.42 \\
(3.91)\end{array}$ & $\begin{array}{c}3.69 \\
(2.29)\end{array}$ & -16.71 & $\begin{array}{c}3.76 \\
(5.77)\end{array}$ & $\begin{array}{c}2.99 \\
(4.99)\end{array}$ & -20.58 \\
\hline C10AA02 & $\begin{array}{c}7.08 \\
(3.78)\end{array}$ & $\begin{array}{c}6.70 \\
(4.14)\end{array}$ & -5.41 & $\begin{array}{c}9.16 \\
(4.30)\end{array}$ & $\begin{array}{c}8.09 \\
(4.03)\end{array}$ & -11.62 & $\begin{array}{c}3.47 \\
(3.04)\end{array}$ & $\begin{array}{c}3.83 \\
(3.68)\end{array}$ & 10.60 \\
\hline C10AA03 & $\begin{array}{c}7.71 \\
(4.41)\end{array}$ & $\begin{array}{c}6.56 \\
(4.27)\end{array}$ & -14.92 & $\begin{array}{l}11.10 \\
(6.20)\end{array}$ & $\begin{array}{c}9.13 \\
(5.66)\end{array}$ & -17.69 & $\begin{array}{c}2.57 \\
(1.81)\end{array}$ & $\begin{array}{c}2.46 \\
(2.13)\end{array}$ & -4.19 \\
\hline C10AA04 & $\begin{array}{c}8.27 \\
(2.14)\end{array}$ & $\begin{array}{c}8.27 \\
(2.14)\end{array}$ & 0.01 & $\begin{array}{l}12.66 \\
(3.56)\end{array}$ & $\begin{array}{l}12.65 \\
(3.56)\end{array}$ & -0.07 & $\begin{array}{c}2.56 \\
(0.72)\end{array}$ & $\begin{array}{c}2.57 \\
(0.72)\end{array}$ & 0.32 \\
\hline C10AA05 & $\begin{array}{c}7.91 \\
(2.99)\end{array}$ & $\begin{array}{c}8.54 \\
(3.49)\end{array}$ & 7.90 & $\begin{array}{l}11.53 \\
(4.50)\end{array}$ & $\begin{array}{l}12.41 \\
(5.29)\end{array}$ & 7.72 & $\begin{array}{c}2.31 \\
(0.90)\end{array}$ & $\begin{array}{c}2.56 \\
(1.04)\end{array}$ & 10.66 \\
\hline C10AA07 & $\begin{array}{c}4.92 \\
(1.35)\end{array}$ & $\begin{array}{c}5.04 \\
(1.30)\end{array}$ & 2.47 & $\begin{array}{c}7.19 \\
(2.05)\end{array}$ & $\begin{array}{c}7.37 \\
(2.00)\end{array}$ & 2.41 & $\begin{array}{c}1.44 \\
(0.41)\end{array}$ & $\begin{array}{c}1.49 \\
(0.39)\end{array}$ & 3.27 \\
\hline \multicolumn{10}{|l|}{ C. By Firm Type } \\
\hline Original Firm & $\begin{array}{c}8.69 \\
(3.62)\end{array}$ & $\begin{array}{c}8.79 \\
(3.63)\end{array}$ & 2.49 & $\begin{array}{l}10.35 \\
(4.91)\end{array}$ & $\begin{array}{l}10.34 \\
(4.90)\end{array}$ & 0.15 & $\begin{array}{c}4.63 \\
(4.84)\end{array}$ & $\begin{array}{c}4.79 \\
(4.94)\end{array}$ & 3.45 \\
\hline Generic Firm & $\begin{array}{c}2.62 \\
(2.03)\end{array}$ & $\begin{array}{c}2.63 \\
(2.01)\end{array}$ & 3.55 & $\begin{array}{c}3.86 \\
(2.32)\end{array}$ & $\begin{array}{c}3.86 \\
(2.28)\end{array}$ & 1.54 & $\begin{array}{c}1.31 \\
(1.77)\end{array}$ & $\begin{array}{c}1.33 \\
(1.78)\end{array}$ & 2.84 \\
\hline Parallel Importer & $\begin{array}{c}7.64 \\
(5.04)\end{array}$ & & & $\begin{array}{c}8.92 \\
(6.07)\end{array}$ & & & $\begin{array}{c}4.40 \\
(5.50)\end{array}$ & & \\
\hline \multicolumn{10}{|c|}{ D. By Patent Status and Firm Type } \\
\hline Off-Patent & $\begin{array}{c}5.69 \\
(4.78)\end{array}$ & $\begin{array}{c}4.90 \\
(4.27)\end{array}$ & -14.01 & $\begin{array}{c}6.67 \\
(5.31)\end{array}$ & $\begin{array}{c}5.79 \\
(4.45)\end{array}$ & -13.16 & $\begin{array}{c}3.46 \\
(4.82)\end{array}$ & $\begin{array}{c}3.01 \\
(4.33)\end{array}$ & -13.04 \\
\hline Original Firm & $\begin{array}{c}9.90 \\
(3.52)\end{array}$ & $\begin{array}{l}10.07 \\
(3.49)\end{array}$ & 4.09 & $\begin{array}{l}10.22 \\
(5.04)\end{array}$ & $\begin{array}{l}10.20 \\
(5.02)\end{array}$ & 0.28 & $\begin{array}{c}6.59 \\
(5.67)\end{array}$ & $\begin{array}{c}6.85 \\
(5.75)\end{array}$ & 11.32 \\
\hline Generic Firm & $\begin{array}{c}2.62 \\
(2.03)\end{array}$ & $\begin{array}{c}2.63 \\
(2.01)\end{array}$ & 3.55 & $\begin{array}{c}3.86 \\
(2.32)\end{array}$ & $\begin{array}{c}3.86 \\
(2.28)\end{array}$ & 1.54 & $\begin{array}{c}1.31 \\
(1.77)\end{array}$ & $\begin{array}{c}1.33 \\
(1.78)\end{array}$ & 2.84 \\
\hline Parallel Importer & $\begin{array}{c}7.82 \\
(5.37)\end{array}$ & & & $\begin{array}{c}8.84 \\
(6.48)\end{array}$ & & & $\begin{array}{c}4.80 \\
(5.82)\end{array}$ & & \\
\hline On-Patent & $\begin{array}{c}7.00 \\
(2.85)\end{array}$ & $\begin{array}{c}7.15 \\
(3.11)\end{array}$ & 2.16 & $\begin{array}{l}10.29 \\
(4.34)\end{array}$ & $\begin{array}{l}10.52 \\
(4.74)\end{array}$ & 2.27 & $\begin{array}{c}2.06 \\
(0.87)\end{array}$ & $\begin{array}{c}2.14 \\
(0.95)\end{array}$ & 4.05 \\
\hline Original Firm & $\begin{array}{c}7.12 \\
(3.11)\end{array}$ & $\begin{array}{c}7.15 \\
(3.11)\end{array}$ & 0.43 & $\begin{array}{l}10.53 \\
(4.74)\end{array}$ & $\begin{array}{l}10.52 \\
(4.74)\end{array}$ & -0.03 & $\begin{array}{c}2.11 \\
(0.95)\end{array}$ & $\begin{array}{c}2.14 \\
(0.95)\end{array}$ & 2.22 \\
\hline Parallel Importer & $\begin{array}{c}6.53 \\
(1.49)\end{array}$ & & & $\begin{array}{c}9.42 \\
(2.16)\end{array}$ & & & $\begin{array}{c}1.90 \\
(0.44)\end{array}$ & & \\
\hline
\end{tabular}

Notes: Fortnightly average prices for a defined daily dose in Danish krones and average percentage change. All figures deflated using consumer prices index with June 2005 as basis. The results are summarized as follows: A. All products, B. Products in the same ATC code, C. Products from the same firm type, and D. Products on-patent and off-patent. Exchange rates in June 2005: DKK $1=\$ 0.1634=€ 0.1343$. Standard deviation in parentheses 
Table 8: Average Change in Shares

\begin{tabular}{|c|c|c|c|}
\hline & Real & Counterfactual & Change in $\%$ \\
\hline & $\begin{array}{c}\text { mean } \\
\text { (std. dev) }\end{array}$ & $\begin{array}{c}\text { mean } \\
(\text { std. dev) }\end{array}$ & $\begin{array}{c}\text { mean } \\
(\text { std. dev) }\end{array}$ \\
\hline \multicolumn{4}{|l|}{ A. All Products } \\
\hline & $\begin{array}{c}0.124 \\
(0.429)\end{array}$ & $\begin{array}{c}0.243 \\
(1.539)\end{array}$ & 96.337 \\
\hline \multicolumn{4}{|l|}{ B. By ATC Code } \\
\hline C10AA01 & $\begin{array}{c}0.161 \\
(0.567)\end{array}$ & $\begin{array}{c}0.355 \\
(2.103)\end{array}$ & 120.109 \\
\hline C10AA02 & $\begin{array}{c}0.010 \\
(0.014)\end{array}$ & $\begin{array}{c}0.168 \\
(0.637)\end{array}$ & 1621.355 \\
\hline C10AA03 & $\begin{array}{c}0.079 \\
(0.176)\end{array}$ & $\begin{array}{c}0.086 \\
(0.148)\end{array}$ & 8.888 \\
\hline C10AA04 & $\begin{array}{c}0.016 \\
(0.015)\end{array}$ & $\begin{array}{c}0.019 \\
(0.030)\end{array}$ & 21.171 \\
\hline C10AA05 & $\begin{array}{c}0.254 \\
(0.284)\end{array}$ & $\begin{array}{c}0.283 \\
(0.268)\end{array}$ & 11.385 \\
\hline C10AA07 & $\begin{array}{c}0.066 \\
(0.044)\end{array}$ & $\begin{array}{c}0.063 \\
(0.059)\end{array}$ & -3.295 \\
\hline \multicolumn{4}{|l|}{ C. By Firm Type } \\
\hline Original Firm & $\begin{array}{c}0.113 \\
(0.214)\end{array}$ & $\begin{array}{c}0.481 \\
(2.299)\end{array}$ & 324.499 \\
\hline Generic Firm & $\begin{array}{c}0.184 \\
(0.625)\end{array}$ & $\begin{array}{c}0.058 \\
(0.137)\end{array}$ & -68.189 \\
\hline Parallel Importer & $\begin{array}{c}0.048 \\
(0.165)\end{array}$ & & \\
\hline \multicolumn{4}{|c|}{ C. By Patent Status } \\
\hline Off-Patent & $\begin{array}{c}0.116 \\
(0.460)\end{array}$ & $\begin{array}{c}0.264 \\
(1.708)\end{array}$ & 127.819 \\
\hline On-Patent & $\begin{array}{c}0.161 \\
(0.234)\end{array}$ & $\begin{array}{c}0.156 \\
(0.215)\end{array}$ & -3.295 \\
\hline
\end{tabular}

Notes: Fortnightly average shares per product in percentage. The results are summarized as follows: A. All products, B. Products in the same ATC code, C. Products from the same firm type, and D. Products on-patent and off-patent. Standard deviation in parentheses. 
Table 9: Average Change in Markups

\begin{tabular}{|c|c|c|c|}
\hline & Real & Counterfactual & Change in $\%$ \\
\hline & $\begin{array}{c}\text { mean } \\
\text { (std. dev) }\end{array}$ & $\begin{array}{c}\text { mean } \\
\text { (std. dev) }\end{array}$ & $\begin{array}{c}\text { mean } \\
\text { (std. dev) }\end{array}$ \\
\hline \multicolumn{4}{|l|}{ A. All Products } \\
\hline & $\begin{array}{c}0.648 \\
(0.137)\end{array}$ & $\begin{array}{c}0.706 \\
(0.215)\end{array}$ & 9.031 \\
\hline \multicolumn{4}{|l|}{ B. By ATC Code } \\
\hline C10AA01 & $\begin{array}{c}0.589 \\
(0.135)\end{array}$ & $\begin{array}{c}0.645 \\
(0.241)\end{array}$ & 9.567 \\
\hline C10AA02 & $\begin{array}{c}0.651 \\
(0.074)\end{array}$ & $\begin{array}{c}0.741 \\
(0.256)\end{array}$ & 13.875 \\
\hline C10AA03 & $\begin{array}{c}0.655 \\
(0.087)\end{array}$ & $\begin{array}{c}0.699 \\
(0.119)\end{array}$ & 6.713 \\
\hline C10AA04 & $\begin{array}{c}0.732 \\
(0.076)\end{array}$ & $\begin{array}{c}0.733 \\
(0.079)\end{array}$ & 0.109 \\
\hline C10AA05 & $\begin{array}{c}0.774 \\
(0.110)\end{array}$ & $\begin{array}{c}0.875 \\
(0.010)\end{array}$ & 13.148 \\
\hline C10AA07 & $\begin{array}{c}0.840 \\
(0.058)\end{array}$ & $\begin{array}{c}0.859 \\
(0.004)\end{array}$ & 2.226 \\
\hline \multicolumn{4}{|l|}{ C. By Firm Type } \\
\hline Original Firm & $\begin{array}{c}0.745 \\
(0.114)\end{array}$ & $\begin{array}{c}0.852 \\
(0.255)\end{array}$ & 14.336 \\
\hline Generic Firm & $\begin{array}{c}0.584 \\
(0.125)\end{array}$ & $\begin{array}{c}0.593 \\
(0.049)\end{array}$ & 1.576 \\
\hline Parallel Importer & $\begin{array}{c}0.631 \\
(0.114)\end{array}$ & & \\
\hline
\end{tabular}

D. By Patent Status

Off-Patent

\begin{tabular}{ccc}
0.617 & 0.674 & 9.103 \\
$(0.125)$ & $(0.225)$ & \\
0.789 & 0.844 & 6.968 \\
$(0.099)$ & $(0.061)$ & \\
\hline
\end{tabular}

Notes: Table 9 reports average markups per defined daily dose in Danish krones. The results are summarized as follows: A. All products, B. Products in the same ATC code, C. Products from the same firm type, and D. Products on-patent and off-patent. Standard deviation in parentheses. 
Table 10: Changes in Profits and Expenditures

\begin{tabular}{|c|c|c|c|c|c|c|c|c|c|}
\hline & \multicolumn{3}{|c|}{ Variable Profits } & \multicolumn{3}{|c|}{ Government Expenditures } & \multicolumn{3}{|c|}{ Consumer Expenditures } \\
\hline & real & counter. & $\begin{array}{c}\text { change } \\
\text { in } \%\end{array}$ & real & counter. & $\begin{array}{c}\text { change } \\
\text { in } \%\end{array}$ & real & counter. & $\begin{array}{c}\text { change } \\
\text { in } \%\end{array}$ \\
\hline & $\begin{array}{c}\text { mean } \\
(\mathrm{sd})\end{array}$ & $\begin{array}{c}\text { mean } \\
(\mathrm{sd})\end{array}$ & $\begin{array}{c}\text { mean } \\
(\mathrm{sd})\end{array}$ & $\begin{array}{c}\text { mean } \\
(\mathrm{sd})\end{array}$ & $\begin{array}{c}\text { mean } \\
(\mathrm{sd})\end{array}$ & $\begin{array}{c}\text { mean } \\
(\mathrm{sd})\end{array}$ & $\begin{array}{c}\text { mean } \\
(\mathrm{sd})\end{array}$ & $\begin{array}{c}\text { mean } \\
(\mathrm{sd})\end{array}$ & $\begin{array}{c}\text { mean } \\
(\mathrm{sd})\end{array}$ \\
\hline \multicolumn{10}{|l|}{ A. All Products } \\
\hline & $\begin{array}{c}1.54 \\
(0.41)\end{array}$ & $\begin{array}{c}4.48 \\
(6.59)\end{array}$ & 189.84 & $\begin{array}{l}10.34 \\
(2.08)\end{array}$ & $\begin{array}{l}18.48 \\
(7.23)\end{array}$ & 78.70 & $\begin{array}{c}3.32 \\
(0.63)\end{array}$ & $\begin{array}{c}7.04 \\
(5.58)\end{array}$ & 112.29 \\
\hline \multicolumn{10}{|l|}{ B. By ATC Code } \\
\hline C10AA01 & $\begin{array}{c}0.91 \\
(0.42)\end{array}$ & $\begin{array}{c}3.75 \\
(6.78)\end{array}$ & 312.10 & $\begin{array}{c}2.73 \\
(0.58)\end{array}$ & $\begin{array}{c}9.62 \\
(8.18)\end{array}$ & 252.40 & $\begin{array}{c}1.34 \\
(0.22)\end{array}$ & $\begin{array}{c}4.51 \\
(6.18)\end{array}$ & 235.42 \\
\hline C10AA02 & $\begin{array}{c}0.02 \\
(0.00)\end{array}$ & $\begin{array}{c}0.25 \\
(0.41)\end{array}$ & $1,365.12$ & $\begin{array}{c}0.19 \\
(0.12)\end{array}$ & $\begin{array}{c}3.38 \\
(5.88)\end{array}$ & $1,700.00$ & $\begin{array}{c}0.09 \\
(0.04)\end{array}$ & $\begin{array}{c}1.10 \\
(1.53)\end{array}$ & $1,173.99$ \\
\hline C10AA03 & $\begin{array}{c}0.14 \\
(0.04)\end{array}$ & $\begin{array}{c}0.10 \\
(0.06)\end{array}$ & -31.52 & $\begin{array}{l}1.78 \\
(0.95)\end{array}$ & $\begin{array}{c}1.32 \\
(0.92)\end{array}$ & -25.94 & $\begin{array}{c}0.47 \\
(0.20)\end{array}$ & $\begin{array}{c}0.35 \\
(0.24)\end{array}$ & -25.41 \\
\hline C10AA04 & $\begin{array}{c}0.02 \\
(0.00)\end{array}$ & $\begin{array}{c}0.02 \\
(0.02)\end{array}$ & 14.94 & $\begin{array}{c}0.21 \\
(0.05)\end{array}$ & $\begin{array}{c}0.25 \\
(0.25)\end{array}$ & 20.55 & $\begin{array}{c}0.05 \\
(0.01)\end{array}$ & $\begin{array}{c}0.06 \\
(0.06)\end{array}$ & 20.98 \\
\hline C10AA05 & $\begin{array}{c}0.39 \\
(0.07)\end{array}$ & $\begin{array}{c}0.30 \\
(0.15)\end{array}$ & -23.47 & $\begin{array}{c}4.98 \\
(1.05)\end{array}$ & $\begin{array}{c}3.47 \\
(1.66)\end{array}$ & -30.28 & $\begin{array}{c}1.25 \\
(0.26)\end{array}$ & $\begin{array}{c}0.90 \\
(0.43)\end{array}$ & -27.66 \\
\hline C10AA07 & $\begin{array}{c}0.07 \\
(0.03)\end{array}$ & $\begin{array}{c}0.06 \\
(0.03)\end{array}$ & -8.96 & $\begin{array}{c}0.48 \\
(0.19)\end{array}$ & $\begin{array}{c}0.47 \\
(0.25)\end{array}$ & -2.08 & $\begin{array}{c}0.12 \\
(0.05)\end{array}$ & $\begin{array}{c}0.12 \\
(0.06)\end{array}$ & -1.85 \\
\hline \multicolumn{10}{|l|}{ C. By Firm Type } \\
\hline Original Firm & $\begin{array}{c}0.57 \\
(0.14)\end{array}$ & $\begin{array}{c}4.19 \\
(6.67)\end{array}$ & 633.50 & $\begin{array}{c}6.61 \\
(2.02)\end{array}$ & $\begin{array}{l}17.50 \\
(7.36)\end{array}$ & 164.55 & $\begin{array}{c}2.32 \\
(0.59)\end{array}$ & $\begin{array}{c}6.78 \\
(5.65)\end{array}$ & 191.47 \\
\hline Generic Firm & $\begin{array}{c}0.81 \\
(0.43)\end{array}$ & $\begin{array}{c}0.29 \\
(0.14)\end{array}$ & -64.44 & $\begin{array}{c}2.18 \\
(0.69)\end{array}$ & $\begin{array}{c}0.98 \\
(0.40)\end{array}$ & -55.05 & $\begin{array}{c}0.58 \\
(0.18)\end{array}$ & $\begin{array}{c}0.26 \\
(0.12)\end{array}$ & -55.14 \\
\hline Parallel Importer & $\begin{array}{c}0.17 \\
(0.10)\end{array}$ & & & $\begin{array}{c}1.54 \\
(0.53)\end{array}$ & & & $\begin{array}{c}0.41 \\
(0.14)\end{array}$ & & \\
\hline \multicolumn{10}{|c|}{ D. By Patent Status } \\
\hline Off-Patent & $\begin{array}{l}1.08 \\
(0.41)\end{array}$ & $\begin{array}{c}4.11 \\
(6.67)\end{array}$ & 279.95 & $\begin{array}{c}4.82 \\
(1.24)\end{array}$ & $\begin{array}{l}14.41 \\
(8.03)\end{array}$ & 198.77 & $\begin{array}{c}1.94 \\
(0.41)\end{array}$ & $\begin{array}{c}5.99 \\
(5.83)\end{array}$ & 209.36 \\
\hline On-Patent & $\begin{array}{c}0.46 \\
(0.06)\end{array}$ & $\begin{array}{c}0.37 \\
(0.18)\end{array}$ & -19.81 & $\begin{array}{c}5.52 \\
(1.02)\end{array}$ & $\begin{array}{c}4.07 \\
(1.90)\end{array}$ & -26.18 & $\begin{array}{c}1.38 \\
(0.26)\end{array}$ & $\begin{array}{l}1.05 \\
(0.49)\end{array}$ & -23.76 \\
\hline
\end{tabular}

Notes: Total variable profits, total government expenditures and total consumer expenditures are fortnightly average in million Danish krones. The results are summarized as follows: A. All products, B. Products in the same ATC code, C. Products from the same firm type, and D. Products on-patent and off-patent. Exchange rates in June 2005: DKK $1=\$ 0.1634=€ 0.1343$. Standard deviation in parentheses 
Table 11: Average Welfare Effects

\begin{tabular}{lcccc}
\hline & real & counterfactual & change & change in $\%$ \\
\hline A. Consumer Surplus & & & & \\
May 2003 - Dec. 2003 & 120.32 & 56.37 & -63.95 & -53.15 \\
Jan. 2004 - Dec. 2004 & 365.55 & 188.27 & -177.28 & -48.50 \\
Jan. 2005 - Mar. 2005 & 28.95 & 16.85 & -12.11 & -41.81 \\
Yearly average & 232.35 & 119.78 & -111.41 & -49.29 \\
\hline B. Variable Profits & & & & \\
May 2003 - Dec. 2003 & 21.67 & 36.50 & 14.83 & 71.44 \\
Jan. 2004 - Dec. 2004 & 47.32 & 171.68 & 124.37 & 251.41 \\
Jan. 2005 - Mar. 2005 & 6.69 & 11.15 & 4.47 & 76.08 \\
Yearly average & 38.03 & 94.54 & 56.51 & 167.50 \\
\hline C. Total Welfare & & & & \\
May 2003 - Dec. 2003 & 141.99 & 92.87 & -49.11 & -34.59 \\
Jan. 2004 - Dec. 2004 & 412.87 & 359.96 & -52.91 & -12.82 \\
Jan. 2005 - Mar. 2005 & 35.64 & 28.00 & -7.64 & -21.43 \\
Yearly average & 270.38 & 214.32 & -54.90 & -20.73 \\
\hline
\end{tabular}

Notes: All figures are in million Danish krones. Exchange rates in June 2005: DKK $1=\$ 0.1634=€ 0.1343$. The average yearly difference in consumer surplus is -111.41 million Danish krones. The average yearly difference in variable profits is 56.51 million Danish krones

Table 12: Average Yearly Expenditures

real counterfactual change change in $\%$

A. Government Expenditures

\begin{tabular}{lcccc} 
May 2003 - Dec. 2003 & 207.23 & 330.43 & 123.20 & 62.45 \\
Jan. 2004 - Dec. 2004 & 251.24 & 507.05 & 255.81 & 101.96 \\
Jan. 2005 - Mar. 2005 & 48.27 & 68.10 & 19.83 & 41.95 \\
Yearly average & 271.51 & 454.22 & 182.71 & 80.90 \\
\hline B. Consumers Expenditures & & & & \\
May 2003 - Dec. 2003 & 65.92 & 97.10 & 31.17 & 48.28 \\
Jan. 2004 - Dec. 2004 & 80.76 & 225.74 & 144.98 & 190.85 \\
Jan. 2005 - Mar. 2005 & 15.76 & 22.04 & 6.28 & 41.14 \\
Yearly average & 87.29 & 162.29 & 75.00 & 123.06 \\
\hline
\end{tabular}

Notes: All figures are in million Danish krones. Exchange rates in June 2005: DKK $1=\$ 0.1634=€ 0.1343$. 


\section{A From pharmacy purchase price to pharmacy retail price}

Using the information in the table below, the pharmacy retail price including VAT (25\%) and fees for a product in the most expensive category before June 2003 is: $p^{c}=1.25 *$ $\left(6.15+0.601 *\left(0.2 * p^{f}+19.8\right)+p^{f}\right)$.

BEK nr. 133 Mar. 142003 Jun. 092003

BEK nr. 368

Jun. 092003

Mar. 262004

BEK nr. 270

BEK nr. 231

BEK nr. 123

BEK nr. 122
From the pharmacy purchase price per package pay $60.1 \%$ of the following amounts:

if $p^{f} \leq$ DKK $30: 60 \%$ of $p^{f}+$ DKK 1.80

if DKK $30<p^{f} \leq$ DKK $60: 40 \%$ of $p^{f}+$ DKK 7.80

if $p^{f}>$ DKK 60: $20 \%$ of $p^{f}+$ DKK 19.80

Prescription's fee excl. VAT: DKK 6.15.

From the pharmacy purchase price per package pay $64.1 \%$ of the following amounts:

if $p^{f} \leq$ DKK $30: 60 \%$ of $p^{f}+$ DKK 1.80

if DKK $30<p^{f} \leq$ DKK $60: 40 \%$ of $p^{f}+$ DKK 7.80

if $p^{f}>$ DKK 60: $20 \%$ of $p^{f}+$ DKK 19.80

Prescription's fee excl. VAT: DKK 6.15.

Mar. 262004 From the pharmacy purchase price per package pay $61 \%$ of the folApr. 122004 lowing amounts:

if $p^{f} \leq$ DKK $30: 60 \%$ of $p^{f}+$ DKK 1.80

if DKK $30<p^{f} \leq$ DKK 60: $40 \%$ of $p^{f}+$ DKK 7.80

if $p^{f}>$ DKK 60: $20 \%$ of $p^{f}+$ DKK 19.80

Prescription's fee excl. VAT: DKK 6.15.

Apr. 122004 From the pharmacy purchase price per package pay $64.3 \%$ of the Feb. 282005 following amounts:

if $p^{f} \leq$ DKK $30: 60 \%$ of $p^{f}+$ DKK 1.80

if DKK $30<p^{f} \leq$ DKK 60: $40 \%$ of $p^{f}+$ DKK 7.80

if $p^{f}>$ DKK 60: $20 \%$ of $p^{f}+$ DKK 19.80

Prescription's fee excl. VAT: DKK 6.15.

Feb. 282005 From the pharmacy purchase price per package pay $59.4 \%$ of the Apr. 012005 following amounts:

if $p^{f} \leq$ DKK $30: 60 \%$ of $p^{f}+$ DKK 1.80

if DKK $30<p^{f} \leq$ DKK $60: 40 \%$ of $p^{f}+$ DKK 7.80

if $p^{f}>$ DKK 60: $20 \%$ of $p^{f}+$ DKK 19.80

Prescription's fee excl. VAT: DKK 6.15.

Apr. 012005 From the pharmacy purchase price per package pay $59.4 \%$ of the Jul. 182005

if $p^{f} \leq$ DKK $30: 44.6 \%$ of $p^{f}+$ DKK 8.29

if DKK $30<p^{f} \leq$ DKK 60: $31.3 \%$ of $p^{f}+$ DKK 12.29

if $p^{f}>$ DKK 60: $18 \%$ of $p^{f}+$ DKK 20.29

Prescription's fee excl. VAT: DKK 6.76.

Notes: These rules and regulations can be found under: www.retsinformation.dk 